DIW BERLIN

Discussion

Papers

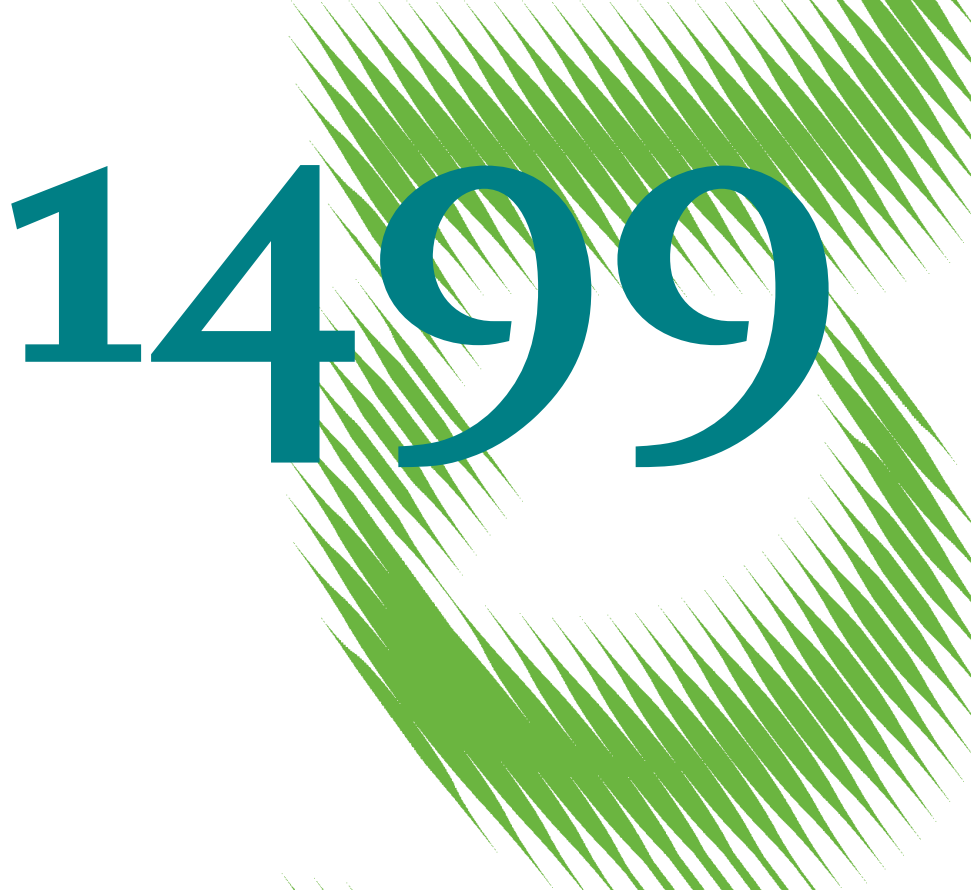

Pension Wealth and Maternal Employment: Evidence from a Reform of the German Child Care Pension Benefit 
Opinions expressed in this paper are those of the author(s) and do not necessarily reflect views of the institute.

IMPRESSUM

(C) DIW Berlin, 2015

DIW Berlin

German Institute for Economic Research

Mohrenstr. 58

10117 Berlin

Tel. +49 (30) $89789-0$

Fax +49 (30) $89789-200$

http://www.diw.de

ISSN electronic edition 1619-4535

Papers can be downloaded free of charge from the DIW Berlin website:

http://www.diw.de/discussionpapers

Discussion Papers of DIW Berlin are indexed in RePEc and SSRN:

http://ideas.repec.org/s/diw/diwwpp.html

http://www.ssrn.com/link/DIW-Berlin-German-Inst-Econ-Res.html 


\title{
Pension wealth and maternal employment: Evidence from a reform of the German child care pension benefit
}

\author{
Andreas Thiemann*
}

August 12, 2015

\begin{abstract}
This paper uses administrative data to investigate how a change in pension wealth affects a mother's employment decision after child birth. I exploit the extension of the child care pension benefit in 1992 as a natural experiment in a regression discontinuity design to estimate short- and medium-run employment effects. In comparison to most family benefits, the child care pension benefit is accumulated upon child birth but only becomes effective on the verge of retirement. Hence, the employment response depends on how a mother discounts future pension benefits. The results suggest that the change in pension wealth does not affect maternal employment, which is not in line with a forward looking rational behavior. Therefore, the child care pension benefit increases maternal old-age income without causing negative employment reactions.
\end{abstract}

Keywords: Natural experiment, female labor supply, pension benefit.

JEL: J13, H55, D19.

*Andreas Thiemann is a PhD Candidate at the DIW Berlin Graduate Center. He is grateful to valuable comments from Peter Haan, Costanza Torricelli, Pia Schober, Michael Neumann, Patricia Gallego-Granados, Johannes Geyer, Holger Lüthen, Adam Lederer and Debora Cobb-Clarks as well as participants from several seminars. Further, he thanks the Research Data Center (FDZ) of the Institute for Employment Research (IAB) for providing the data. Finally, he thanks the Forschungsnetzwerk Alterssicherung (FNA) for the PhD scholarship. Any remaining errors are his own. An earlier version of the paper has been published as the Netspar Discussion Paper No. 01/2015-003. 



\section{Introduction}

Child birth causes a natural interruption of employment of mothers. In the months following child birth many mothers focus on child care while dedicating less time to paid work (cf. Schönberg and Ludsteck (2014)). These employment interruptions reduce paid pension contributions and, ultimately, increase the risk of old-age poverty among mothers. In order to mitigate this risk, Germany introduced the child care pension benefit in 1986. Since then, the benefit increases a mother's pension entitlements in compensation for periods when child care precluded work. However, despite the positive impact on old-age income, the child care pension benefit introduces negative work incentives to mothers. Mothers whose pension entitlements are already higher through benefit accrual, do not have to become employed in order to accumulate the same amount of pension entitlements through compulsory pension contributions. Furthermore, pension entitlements from employment were withdrawn against those based on the child care pension benefit in the first decade after its introduction. A large employment reduction due to the benefit provision would counteract the intended positive impact of the child care pension benefit on old-age income of mothers.

This paper tests whether mothers react to an increase in pension wealth by reducing employment based on administrative data. Exploiting an extension of the child care pension benefit in 1992 as a natural experiment, I estimate short- and mediumrun employment effects. Looking at early employment responses is particularly important, as the length of employment interruptions paves the way for the individual long-term earnings potential. An extended absenteeism from the labor market generally lowers a mother's lifetime earnings through human capital depreciation and lower accumulated work experience (Shapiro and Mott, 1994; Mincer and Ofek, 1982; Albrecht et al., 1999).

The identification strategy exploits the pension reform in 1992 in a regression discontinuity design. The reform prolonged the provision period of the child care pension benefit from one to three years for all newborns starting from January 1992. The implied economic gain for a 30-years old mother amounts up to $€ 2,500$, in net 
present values. ${ }^{1}$ However, in 1992 not only the child care pension benefit but also parental leave was extended, affecting maternal employment as well. Parental leave increased from 18 to 36 months for the same newborns from January 1992. Therefore, this paper has to disentangle the employment effect of the extended child care pension benefit from the parental leave extension. Schönberg and Ludsteck (2014) investigated how mothers changed their employment in response to the parental leave extension in 1992, finding a short-run employment reduction. To disentangle the effects of the two reforms, I focus on mothers who were not employed three moths prior to giving birth. This group of mothers was only affected by the longer provision of the child care pension benefit. Then, I compare the employment behavior of mothers who had a child in the last months of 1991 - subject to the old child care pension benefit regulation - to those who had a child early in 1992 - benefiting from the extended benefit duration - to identify the causal short- and medium-run employment response of mothers to the child care pension benefit.

Most family benefits and transfers in Germany become effective shortly after child birth. Among them the child allowance (Kindergeld) is a prime example. ${ }^{2}$ Parents are entitled upon child birth and it is generally granted until a child turns 18 years old, without means-testing. Rainer et al. (2012) analyzed the impact of the child allowance on maternal employment. They find that the child allowance tends to reduce maternal employment, particularly among mothers with a low earnings potential.

In contrast to most family benefits and transfers, the child care pension benefit, however, becomes effective at the verge of retirement and not when it is accrued. Hence, a mother's employment response to these dynamic incentives depends on her discounting behavior. Imagine a rational forward-looking young mother, she would fully consider the impact of the child care pension benefit on old-age income in her

\footnotetext{
${ }^{1}$ The calculation assumes retirement at 65 and death at 83 and compares the economic consequences of having a child in January 1992 compared to December 1991. Appendix A provides the details.

${ }^{2}$ In 2013 the child allowance amounted to EUR 184 for the first and second child, EUR 190 for the fourth and EUR 215 for each subsequent child. (http://www. arbeitsagentur. de/web/content/DE/ BuergerinnenUndBuerger/FamilieundKinder/KindergeldKinderzuschlag/Detail/index.htm? dfContentId=L6019022DSTBAI486116).
} 
decision to re-enter employment after child birth. However, a mother with a short planning horizon or a high personal discount factor is less affected by the child care pension benefit.

The results of the paper can be summarized as follows: The empirical findings suggest that the change in pension wealth does not affect maternal employment, which is not in line with a forward looking rational behavior. Therefore, the child care pension benefit increases maternal old-age income without causing negative employment reactions. The remainder of the paper proceeds as follows: The next section introduces the institutional background of the pension reform. Then, the economic incentives are explained in detail. Section 4 presents the identification strategy. Next, the data set is described and the empirical results are discussed. The final section concludes.

\section{Related literature}

Different strands of literature are related to this paper. First, it is linked to the literature that looks at the impact of family policies on mothers' employment. As examples of family policies, I focus on parental leave and child care policies. However, since the timing of when the benefit becomes affective differs from most family policies, the second part of this literature review focuses on individual responses to the public pension system and discounting behavior.

\section{Parental leave and maternal employment}

A cross-country study by Ruhm (1998) finds that a moderate parental leave duration is associated with a stronger labor market attachment of mothers. Several studies report only weak or no significant effects of parental leave on maternal employment (Baum and Charles, 2003; Klerman and Leibowitz, 1999; Waldfogel, 1999). However, they focus on the US maternity leave scheme, which exhibits a rather short provision period compared to parental leave durations in other Western countries. Studies find indeed that mothers tend to adjust their employment behavior when (paid) parental leave is provided (Lalive and Zweimüller, 2009; Lalive et al., 2014; Bergemann and Riphahn, 2010; Kluve and Tamm, 2009; Geyer et al., 2014; Schönberg 
and Ludsteck, 2014).

Lalive and Zweimüller (2009) exploit two subsequent parental leave reforms in Austria as natural experiments. They find that an extension of the parental leave duration reduces substantially short-run labor supply of mothers. In the long-run, however, the longer absenteeism from the labor market does not seem to harm employment and earnings of mothers. Lalive et al. (2014) show that a combination of job-protection and cash benefits is most effective to encourage mothers in returning to the labor market after childbirth.

In Germany, several studies exploit the parental leave reform in 2007 that halved the duration of paid parental leave while substantially increasing the cash benefit. Bergemann and Riphahn (2010) and Kluve and Tamm (2009) exploit it as a natural experiment and find that the parental leave reform increased the mother's willingness to (re-)enter employment in the second year after child birth. Geyer et al. (2014) document an employment reduction of mothers in the first year after child birth due to the parental leave reform in 2007. In the second year, however, only certain subgroups of mothers (low-income and East-Germans) increased employment.

For the identification strategy that I apply in this paper the work by Schönberg and Ludsteck (2014) and Dustmann and Schönberg (2011) is most related. They evaluate the impact of several major expansions in parental leave coverage in Germany between 1973 and 1993 on mothers' labor market outcomes as natural experiments. Overall, they find that mothers respond to extensions of parental leave by reducing labor supply in the short-run, but not in the long-run. Dustmann and Schönberg (2011) document that these parental leave expansions did not improve long-run outcomes of children. The extension of parental leave from 18 to 36 months in 1992 is particularly relevant for this paper as both, the extension of parental leave and of the child care pension benefit, became effective simultaneously in January 1992. Schönberg and Ludsteck (2014) find that mothers substantially reduced labor supply in the short-run in response to this parental leave expansion in 1992.

\section{Child care policies and maternal employment}

A large body of literature investigates the impact of child care provision on maternal employment. Summaries of empirical studies are provided by Anderson and Levine 
(1999), Blau and Currie (2006) and Blau and Tekin (2007). The first set of studies relies on structural models (Guner et al., 2013; Geyer et al., 2014; Haan and Wrohlich, 2011). For the US, Guner et al. (2013) find that a hypothetical fully subsidized provision of child care to all households would substantially increase participation rates among married females by 10\%. For Germany, Haan and Wrohlich (2011) find that higher subsidized child care, conditional on employment, increases maternal employment.

The main difficulty in the identification of employment effects is the endogeneity of child care. Many studies rely therefore on quasi-experimental approaches, mainly the difference-in-difference method, often exploiting an expansion of subsidized child care as a natural experiment (Havnes and Mogstad, 2011; Cascio, 2009; Bauernschuster and Schlotter, 2013; Givord and Marbot, 2013; Nollenberger and Rodriguez-Planas, 2011; Bettendorf et al., 2012; Lefebvre et al., 2009; Lundin et al., 2008; Fitzpatrick, 2010). Cascio (2009) exploits the large expansion of kindergarten seats for 5-year old children, offered by public schools since the mid 1960s in the US, as a natural experiment. He finds that single mothers substantially increased their labor supply, while married mothers did not respond. In a similar vein, Havnes and Mogstad (2011) rely on large expansion of subsidized childcare in Norway. Estimating employment responses, they exploit spatial and temporal variation on the municipality level. Their empirical analysis is conducted using administrative data that covers the entire Norwegian population over the relevant period. In contrast to the previous study, however, they find only little empirical support for the hypothesis that subsidized childcare increases maternal employment. Finally, a recent German study exploits the introduction of the legal claim to a place in kindergarten for three- to six-year old children in 1996 in West Germany to estimate the effect on maternal employment (Bauernschuster and Schlotter, 2013). Results from two different quasi-experimental approaches consistently document large positive effects on employment among mothers whose youngest child is three to four years old.

To sum up, there is substantial evidence on how maternal employment is affected by parental leave and child care policies. The degree of the employment response of mothers to family policies depends on the financial incentives and the institutional design. However, since the timing of becoming effective of the child care pension 
benefit differs to most family benefits, the extend to which mothers adjust employment to the pension benefit remains an empirical question.

\section{Public pension system and individual decisions}

Next, this paper relates to the literature that investigates the impact of public pension systems on individual behavior. Gruber and Wise (2002) summarize the results from a large international cross-country research project based on micro-data. The authors emphasize that the provision of social security programs is a key determinant of the retirement decision.

The link between social security wealth and retirement has been investigated for Germany (Berkel and Börsch-Supan (2004); Geyer and Steiner (2014); Hanel (2010)). Applying an option value model, Berkel and Börsch-Supan (2004) simulate individual retirement responses to various pension reform options in Germany. They predict that the introduction of an early-retirement disincentive in 1992, a reduction of pension payments by about $3.6 \%$ for each year of early retirement, delays effective retirement by almost two years among men. Hanel (2010) exploits the implementation of the adjustment factors in 1992 as a natural experiment when estimating its long-term impact on retirement. In line with the previous paper, she finds that individuals notably retire later.

Overall, the literature shows the link between the provision of public pensions and the individual retirement decision. However, there is little evidence on the impact of the pension system on employment when being younger. This paper adds to this literature by analyzing the impact of a pension benefit on the employment decision of young mothers.

Finally, the extent to which changes in social security wealth affect the behavior of individuals depends on the individual adjustment horizon. Gale (1998) emphasize the importance of the remaining adjustment period until retirement, when estimating the savings response to a change in social security wealth. A young worker has, on average, more time to adjust individual savings to the change in social security wealth, compared to a 60-years-old. Further, the planning horizon as well as the individual discounting behavior determines the extend to which individuals react to changes in social security wealth. Gustman and Steinmeier (2005) incorporate 
individual-specific time preferences in their model of retirement and saving in order to obtain a better representation of actual individual behavior. Further, individual discount rates tend to decline when education increases. To sum up, these studies document that the extend to which individuals respond to changes in their social security wealth depends inter alia on individual discounting.

\section{Institutional background}

\subsection{Child care pension benefits}

This section describes the accumulation of pension entitlements in the German pension system (GRV) and further introduces the institutional setting of the child care pension benefit. The GRV links the amount of pension payments to the value of a pensioner's accumulated pension contributions over working life. Pension payments are calculated based on a formula that incorporates accumulated pension contributions, the timing of retirement, an adjustment factor and the current value of pension contributions. The formula that calculates the pension benefits is described in detail by Boersch-Supan and Wilke (2004). The main determinant of pension payments is the sum of individual accumulated pension points (Entgeltpunkte). One pension point represents annual pension contributions made by a reference contributor earning the average income. Upon retirement, one pension point corresponds to pension payments of $€ 28$ per month (West-Germany, July 2012 values). ${ }^{3}$ The monetary equivalent of a pension point is adjusted each year according to change of average gross earnings and several adjustment factors. Faik and Köhler-Rama (2009) describe the adjustment mechanism in detail.

After this brief introduction into the German pension system, we focus on the child care pension benefit. Table 1 depicts the development of the child care pension benefit from its introduction in 1986 til 1999. In general, child care pension benefits can be regarded as pension contributions in periods of child care that are made by the State. Hence, the child care pension benefit increases total pension entitlements of recipients. From 1986 till 1992, mothers accrued a maximum of 0.75 pension points

\footnotetext{
${ }^{3}$ http://www.deutsche-rentenversicherung.de/cae/servlet/contentblob/238644/ publicationFile/52076/aktuelle_daten_2013.pdf
} 
Table 1: Child care pension benefit in the GRV 1986-1999

\begin{tabular}{c|c|c}
\hline \hline Reform & $\begin{array}{c}\text { Child care pension benefit } \\
\text { (maximum benefit) }\end{array}$ & Duration \\
\hline 1986 & 0.75 pension points (PP) & 1 year \\
\hline 1992 & 0.75 PP & 3 years \\
\hline 1999 & $\begin{array}{c}1 \text { PP + additivity against } \\
\text { pension contributions from } \\
\text { employment }\end{array}$ & 3 years \\
\hline \hline
\end{tabular}

Source: Own illustration.

in the first year following child birth. ${ }^{4}$ However, the benefit was granted conditional on employment. In particular, pension contributions stemming from child care periods were fully withdrawn against compulsory contributions from employment. Accordingly, an employed mother with earnings equivalent to $50 \%$ of the average only received 0.25 pension points due to the child care pension benefit. The remaining 0.5 pension points were withdrawn against the compulsory pension contributions from employment. Therefore, a mother only gained from the child care pension benefit if she was either not employed or if she earned less than $75 \%$ of the average (corresponding to 0.75 pension points) in the first year after child birth.

The first change of the child care pension benefit was adopted in December $1989^{5}$ and implemented two years later in January 1992. The reform tripled the child care pension benefit duration from one to three years, but only for newborns born on or after January 1, 1992. Hence, women with a child meeting this condition were entitled to the maximum benefit of 2.25 pension points ( 3 years $x 0.75$ pension points) instead of 0.75 pension points, granted for births on or before December 31, 1991. Converted into pecuniary values of 2012, the maximum gain of 1.5 additional pension points results in a monthly payment of $€ 42$ upon retirement til death. As an example, the maximum gain from the reform of a mother, aged 30 years in January 1992, amounts to $€ 2640$ (expressed in 2012 net present discounted values). The underlying calculation assumes that the mother retires at the age of 65 with a life

\footnotetext{
${ }^{4}$ The benefit was only granted to mothers born after 1921. In principle, also fathers are entitled. However, predominantly mothers are recipients of the child care pension benefit.

${ }^{5}$ by the Pension Reform Law 1992 (Rentenreformgesetz 1992).
} 
expectancy of 83 years, based on a discount rate of 3\% (details are provided in Appendix A). Since pension contributions stemming from employment were still offset against those from child care pension benefits, mothers were only entitled to the full child care pension benefit if they were not being employed in the three years after child birth.

Since subsequent reforms changed the incentives for all mothers, regardless of a child's date of birth, I use only the variation that is implied by the child care pension benefit reform of 1992. Therefore, only the time period before 1999 is considered in the empirical analysis. This allows to study the short- and medium-run employment effects of the child care pension benefit extension in 1992. Nevertheless, the 1999 reform of the child care pension benefit, described here, consisted of two main changes: First, it increased the generosity of the child care pension benefit from 0.75 to one pension point. Second, it removed the employment penalty. Pension contributions from employment were not withdrawn anymore against those from child care periods if the sum of both did not exceed the contributions based on the contribution ceiling.

\subsection{Economic incentives}

This section illustrates by a simple example how the extension of the child raising pension benefit in 1992 affects the employment decision of mothers. In general, the degree to which mothers consider the economic incentives in their employment decision depends on the individual discounting behavior. While mothers with a high discount rate or a short decision-making horizon are less prone to react to the benefit provision, perfectly rational mothers would fully incorporate the future implications of the pension benefit. In principle, the extension of child care pension benefits from one to three years in 1992 lowered the incentives for mothers to (re)enter the labor market during the three years following child birth. Since pension contributions are accumulated through child care pension benefits, no compulsory pension contributions - resulting from employment - had to be made. To illustrate the economic incentives, let us consider the following example of two young mothers: While the first mother (A) has her child in December 1991, the second mother 
(B) has her child in January 1992. In addition, I assume that only the accrual of pension contributions matters for a mother's employment decision. Then, mother B has no incentive to (re-)enter employment in year two and three after child-birth if she would earn less than $75 \%$ of the average since those pension contributions would be fully withdrawn. In contrast, mother A faces positive work incentives in that period because child care pension benefits expire after the first year. The accrual of pension entitlements is clearly not the only determinant of a mother's employment decision. Nevertheless, this example illustrates that a mother who did not benefit from the child care pension benefit extension has an incentive to return earlier into employment.

\section{Identification}

This paper analyzes the impact of an extension of the child care pension benefit on mothers' employment in a regression discontinuity design. The identification exploits the specific design of the pension reform in 1992. In order to identify the reform effect, I construct two groups. The control group consists of mothers who had a child shortly before the policy change was implemented (in 1991 Q4). These mothers are entitled to one year of child care pension benefits. The treatment group is based on mothers who had a child shortly after the implementation of the reform (in 1992 Q1) and thus they are entitled to three years of child care pension benefits. Comparing mothers who had a child close ${ }^{6}$ to this cut off date January 1, 1992, the only institutional discontinuity between the treatment and the control group is the different duration of child care pension benefits. In this way, a difference in the employment behavior across both groups can be attributed to the longer duration of the child care pension benefit. In comparison with other "typical natural experiment strategies" (e.g. differences-in-differences or instrumental variables), the regression discontinuity design requires only mild assumptions and isolates "treatment variation that is as good as randomized" (Lee and Lemieux, 2010, p. 282). In

\footnotetext{
${ }^{6}$ In the baseline specification "close to the cut-off date" refers to having a child in the last quarter 1991 vs. the first quarter 1992. As a robustness check, however, I expand the the bandwidth to \pm six months.
} 
recent years, economists increasingly adopted the regression discontinuity design to a broad range of economic problems. ${ }^{7}$ This paper analyzes the employment response of mothers to the extension of child care pension benefits. Therefore, the dependent variable is the binary employment status. A mother can either be employed (one) or not (zero). The corresponding probit model is defined as follows: 8

$$
\operatorname{Pr}\left(\text { employed }_{i t}\right)=\Phi\left(\alpha+\beta_{1} \text { post }_{i}+\gamma^{\prime} X_{i t}\right)
$$

where $\Phi$ is the cumulative distribution function of the standard normal distribution, $i$ indicates the mother and $t$ the age of a child. post is one if a mother is in the treatment group, and zero if she is in the control group. $X$ is a vector of control variables: Age, age ${ }^{2}$, education, region, number of children, prior employment and German nationality. On the basis of $\beta_{1}$ the marginal effect, that captures the impact of the child care pension benefit extension in 1992, can be calculated. Since mothers are observed in the entire period following child birth, the model can be estimated for the identical sample at various points in time. In the following, it is estimated at a child age of 18 , 28, 36, 60 and 120 months. Estimating the model conditional on child age ensures that at month $t$ all mothers had been entitled to $t$ months of child care pension benefits, regardless of the calender month.

For assigning mothers into treatment and control group conditional on their child's birth date, the crucial prerequisite is that other pension reforms were dependent on the mother's and not the child's date of birth. Therefore, other pension reforms would have affected mothers in both groups in the same way. Further, only mothers who gave birth to their last child are considered since subsequent births naturally would reduce a mother's propensity to (re-)enter employment. Then, to disentangle

\footnotetext{
${ }^{7}$ Angrist and Lavy (1999) apply the identification strategy in estimating the impact of class size on student test scores in Israel. Oreopoulos (2006) estimates the returns to education by exploiting the design of a compulsory schooling law in the UK. Geyer et al. (2014) estimate the impact of the German parental leave reform 2007 on maternal employment using a regression discontinuity strategy. An overview of the application of regression discontinuity designs to economic problems is given by Lee and Lemieux (2010).

${ }^{8}$ The OLS model is specified analogously by

$$
\text { Employed }_{i t}=\alpha_{0}+\text { ppost }_{i}+\gamma^{\prime} X_{i t}+e_{i t}
$$

where the variables are defined as in the probit model and e captures the error term.
} 
the impact of the child care pension benefit reform on maternal employment from the parental leave reform, I only consider mothers who were not employed three months prior to child birth. In general they cannot benefit from parental leave, since there is no pre-child birth employment they could return to. However, theoretically a mother could have been entitled to prolonged parental leave from an earlier child birth if she had given birth to the subsequent child within 18 months. To ensure that the results are not confounded, I re-estimate the model based on a sample of mothers who had a child in 1991Q4 or 1992Q1, but not in the 18 months before. To sum up, the baseline sample is based on mothers who had their last child in 1991Q4 or in 1992Q1 and who were not employed three months prior to child birth.

The identification strategy is only valid if a mother cannot self-select into the treatment group by strategically choosing her child's date of birth. Mothers principally have an incentive to self-select into the treatment group to take advantage of the longer benefit provision. Since the child care pension benefit extension was adopted by the parliament in December 1989 two years before becoming effective, parents theoretically could self-select into the treatment group by strategically choosing 1992 instead of 1991 as their child's year of birth. The literature documents a strategic timing of births for several policy changes (Neugart and Ohlsson, 2013; Gans and Leigh, 2009; Tamm, 2012). Nevertheless, a child's birth date can only partially be controlled by parents. Ekberg et al. (2013) emphasize that birth, as such, is a "random event", since parents cannot completely control the timing of conception. The duration of pregnancy follows a normal distribution of 40 weeks and a standard deviation of two weeks (Ekberg et al., 2013, p. 135). In addition, parents who strategically chose 1992 as a child's year of birth, most likely prefer a birth date not in the first quarter to prevent the risk of having a premature baby in 1991. However, it might still be possible that particularly around the cut-off date $(1 / 1 / 1992)$ births have been postponed. In order to address that concern, Dustmann and Schönberg (2008, Appendix A) analyze the timing of births shortly around the turn of the year 1991/92. They find no evidence that there has been a strategic timing of births around the turn of the year 1991/92. As an additional robustness check, I exclude births in January and December from the sample and re-estimate the model. ${ }^{9}$ Further, I compare the total

\footnotetext{
${ }^{9}$ The results are in documented in section 5.4 .
} 
number of births around ( \pm six months) the turn of the year 1991/92 with the two subsequent years, without finding a strategic timing of birth behavior. The results are described in detail in Appendix B. Furthermore, to check for random selection into treatment and control group, I investigate if the distribution of observable characteristics differs across both groups. This is the standard test in empirical work to check for random assignment of individuals into treatment and control group (Lee and Lemieux, 2010, p. 296). The descriptive comparison of observable characteristics, in section 5.2, shows a similar distribution across both groups. This provides evidence against a non-random selection of mothers into the treatment and control group.

The identification strategy implicitly assumes that mothers are aware of the extension of the child care pension benefit. It is an assumption inherent in all quasiexperimental designs that evaluate the impact of policy changes on individual behavior. I have anecdotal evidence that the German Pension Insurance increased substantially their effort to inform about the child care pension benefit extension in 1992 by publishing brochures and providing information to the media.

\section{Data and Results}

Next, this section describes the data and sample selection followed by the discussion of results.

\subsection{Data}

This paper relies on the administrative Biographical Data of Social Insurance Agencies in Germany (BASiD, version 1951-2009). ${ }^{10}$ The data results from a linkage of two administrative data sources from the Statutory Pension Insurance and the Federal Employment Agency. The two data sets are merged via the identical social security number that serves as the unique individual identifier (Hochfellner et al., 2012). First, a sample was selected from the Sample of Insured Persons and their

\footnotetext{
${ }^{10}$ The weakly anonymized version of BASiD was accessed at the Data Research Center of the Federal Statistical Office in Berlin and provided by the Institute for Employment Research (IAB) in Nuremberg.
} 
Insurance Accounts (VSKT) 2007 of the German pension system. Then, this sample was enriched with individual information from the Federal Employment Agency. The joint data set provides spell information about the employment history for each individual on a daily level from the first entry until 2007. In addition, BASiD contains information about education ${ }^{11}$, birth dates of children and several individual and work-related characteristics. However, for some individuals not all information is available. Mainly the educational degree is missing. About 35\% of all mothers in the sample lack information about education. Therefore, the estimation results are displayed for specifications with and without covariates.

In comparison with other data sources, BASiD has several advantages. Survey data, e.g. the German Socio Economic Panel (GSOEP), is not applicable since the sample size would be too small to apply the regression discontinuity design. Most other administrative data sets are based on Social Security Records. Schönberg and Ludsteck (2014) rely on them in their evaluation of the parental leave expansion in 1992. While Social Security Records provide large samples of persons who were employed or searching for a job, they are less representative for mothers with a weaker link to the labor market. In particular, the correct child's birth date can only be deduced based on maternity leave usage (Schönberg and Ludsteck, 2014). Consequently, a mother who was not employed prior to having a child cannot be identified as a mother based on the Social Security Records. In contrast, since BASiD is based on a sample of the VSKT of the German pension system, a mother who was not employed prior to child birth or later is part of the sample. Hence, BASiD covers the large group of mothers with a weaker link to the labor market better than the Social Security Records.

The sample is based only on West-German mothers, since fertility dropped substantially in East Germany after the re-unification. Selective fertility in East Germany would be particularly problematic since the empirical analysis relies on births shortly after the German re-unification. Further, I exclude all mothers who are coded as miners and crafts-persons, who partially have separate pension funds. In addition, the sample relies only on "validated" pension accounts. For these accounts, the

\footnotetext{
${ }^{11}$ In order to improve quality of the education variable, the imputation procedure, suggested by Fitzenberger et al. (2005), is applied.
} 
self-declared information of the insured was cross-checked by the German pension Insurance to ensure its reliability. However, the share of "non-validated" accounts is only $10 \%$ in BASiD. Finally, a mother is only selected into the sample if she was not younger than 18 and not older than 45 years at delivery. The baseline sample consists of 553 (328 when including covariates) mothers.

\subsection{Descriptive evidence}

This section provides first descriptive results and it further compares the distribution of observable characteristics across the treatment and the control group. The share of employed mothers is plotted by child age, separately for three different samples of mothers who had their last child in 1991Q4 or in 1992Q1. The first sample is based on all mothers independent of their employment status prior to child birth (total sample). The total sample can then be split up into mothers who were employed three months before child birth (employed sample) and mothers who were not employed three months before child birth (baseline sample). Within each of the three samples, the employment quota is plotted separately for mothers who had their child in 1991Q4 relative to mothers with a child birth in 1992Q1.

Figure 1 plots the employment pattern for the total sample by child age in months. Around child birth maternal employment is practically zero, since the German maternity leave regulation prohibits employment in the first eight weeks of a newborn. Then, the share of employed mothers increases steadily for all mothers to around $10 \%$. However, from 15-18 months the quota increases strongly and remains higher until month 36 among mothers who had a child in 1991Q4 compared to mothers with a child birth in 1992Q1. This employment pattern is in line with the response to the parental leave extension in 1992 that was documented by Schönberg and Ludsteck (2014). ${ }^{12}$ Mothers with a child birth in 1992Q1 who were employed prior to delivery could take advantage of the extension of parental leave from 18 to 36 months.

When restricting the total sample to employed mothers three months before child birth (employed sample) in Figure 2, the parental leave reform effect becomes even

\footnotetext{
${ }^{12}$ In order to replicate their results based on BASiD, I re-estimate the model by Schönberg and Ludsteck (2014), obtaining similar results.The findings are in Table 11 in Appendix D.
} 
Figure 1: Maternal employment by child age, based on all mothers independent of pre-child birth employment (total sample)

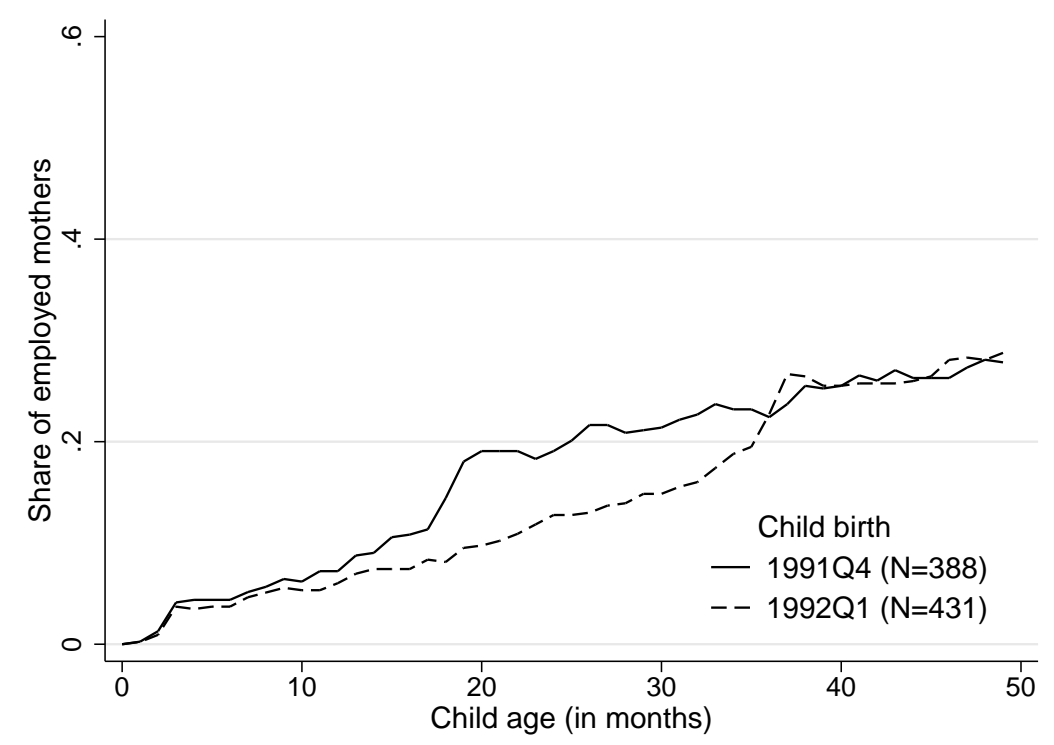

Data source: BASiD (version 1951-2009).

Figure 2: Maternal employment by child age, based on mothers who were employed three months prior to child birth (employed sample)

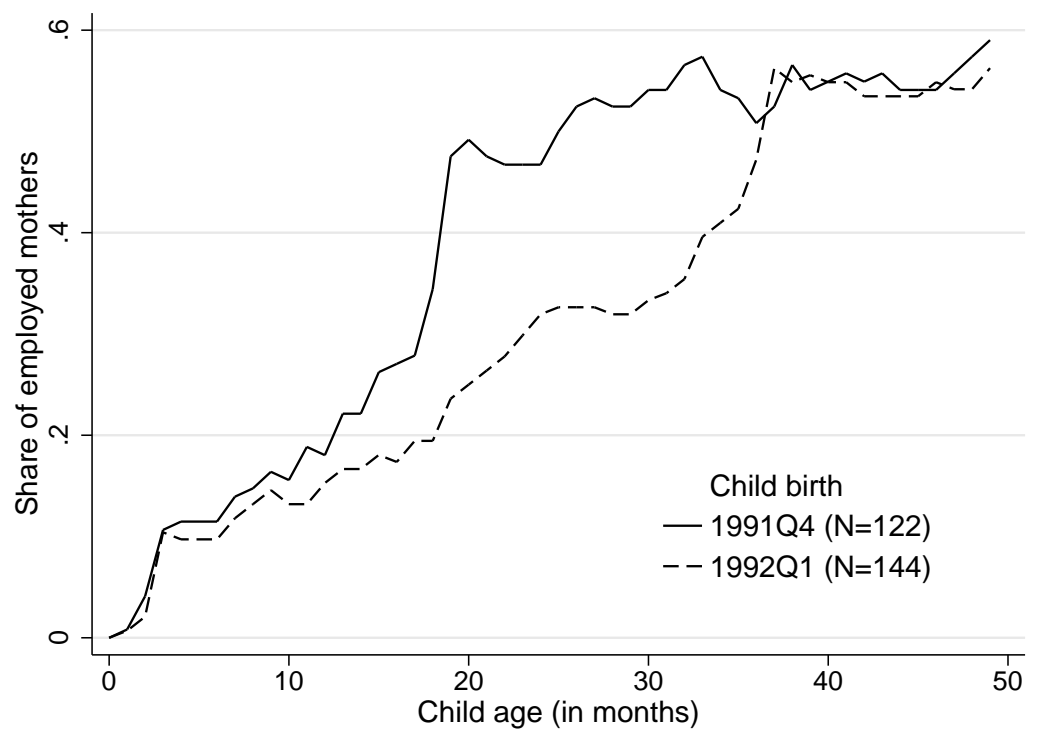

Data source: BASiD (version 1951-2009). 
Figure 3: Maternal employment by child age, based on mothers who were not employed three months prior to child birth (baseline sample)

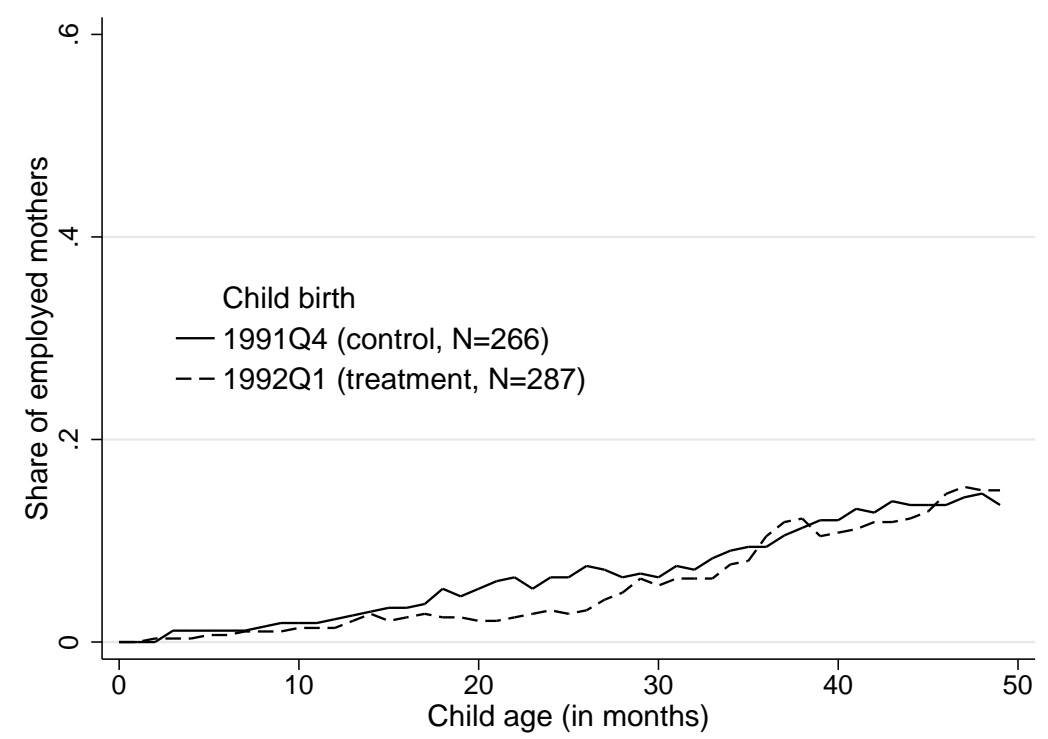

Data source: BASiD (version 1951-2009).

more pronounced. Between month 15 to 36 the employment quota is substantially higher among mothers who had their last child in 1991Q4 relative to mothers with a child birth in 1992Q1. In the employed sample, all mothers who had a child in 1992Q1 relative to 1991Q4 gained from the parental leave extension, which indicates a stronger reaction to the parental leave reform. Overall, since mothers are selected conditional on being employed before child-birth, it is not surprising that the share of mothers in employment is generally higher and increases faster for all mothers than in the total sample. To sum up, this descriptive analysis of maternal employment in the total and the employed sample underlines the importance to separate the impact of the child care pension benefit extension on a mother's employment decision from the simultaneous parental leave reform.

Finally, Figure 3 plots the employment pattern for the treatment and control group of the baseline sample. First of all, the share of employed mothers generally remains lower until month 50 than in the total- and the employed sample since only mothers who were not employed three months before child birth are selected into the baseline sample. The child care pension benefit extension in 1992 provides incentives to 
the treatment group to postpone the employment entry after child birth. The plot shows that the employment pattern is similar across treatment and control group, independent of child age. Nevertheless, between month 17 and 29, mothers in the control group appear to be more likely to be employed than in the treatment group. But this difference is not statistically significant. Summing up, these descriptive findings provide first evidence against an employment response of mothers to the child care pension benefit extension in 1992.

In the next step, we focus on the distribution of observable characteristics across treatment and control group in Table 2. If mothers are randomly assigned into treatment- and control group, then we would expect a similar distribution of covariates across both groups. 


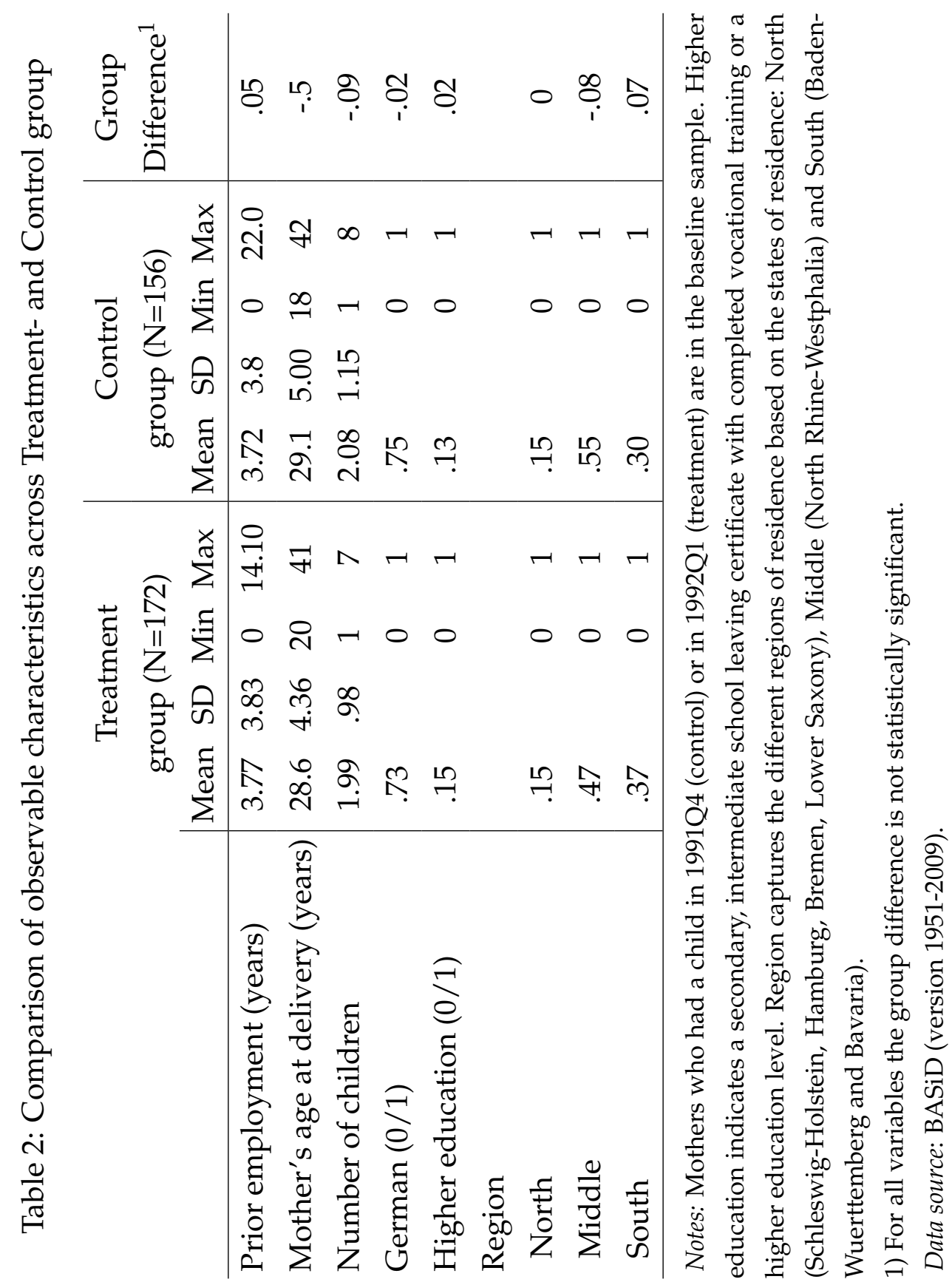


While the first two columns compare the observable characteristics across both groups, the third column reports the corresponding mean difference. For all variables the mean difference is statistically insignificant, indicating a similar distribution across both groups. Mothers in both groups had been employed on average for about four years before the birth of their last child. Looking at nationality, the share of German mothers is similar in the treatment $(73 \%)$ and in the control group (75\%). Next, we focus on the distribution of education across both groups. Higher education indicates whether a mother holds a secondary, intermediate school leaving certificate with completed vocational training or a higher degree. While the share of mothers with higher education is relatively low in both groups, it is slightly higher $(15 \%)$ in the treatment than in the control group $(13 \%)$. However, the difference is not statistically significant. Region is constructed based on the state of residence: North (Schleswig-Holstein, Hamburg, Bremen, Lower Saxony), Middle (North Rhine-Westphalia) and South (Baden-Wuerttemberg and Bavaria). While Region varies somewhat across both groups, the difference is statistically insignificant. In conclusion, mothers in the treatment and the control group share relatively similar observable characteristics.

\subsection{Main estimation results}

This section discusses the estimation results, which suggest that the child care pension benefit has no impact on maternal employment. I report estimates for the probit and the OLS model and differentiate by the inclusion of the control variables. Since all mothers in the sample are observed in the entire time span, I can estimate the model at different child ages, i.e. at 19, 28, 36, 60 and 120 months. Repeating the estimation at different points in time allows for the distinction between short- and medium-run employment effects among mothers. Table 3 reports the treatment estimates that refer to the impact of the child care pension benefit extension in 1992 on mothers' employment. While the OLS model reports the estimated treatment coefficient, the Probit model shows the average marginal effect. The complete estimation results, including estimates for controls are reported in Appendix D (Table 7 contains OLS results and Table 6 the results of the probit model). In the following, I 
focus only on specifications that include control variables.

Beginning at a child age of 19 months, the estimated treatment effect, taken at face value, implies a three percentage points reduction of the employment probability due to the extended provision of the child care pension benefit. In the light of the low employment share among mothers - when a child is 19 months old - a three percentage point increase would imply a large employment reduction. However, the estimated reform effect is statistically insignificant. Despite the limited sample size, the standard errors are still moderate. Next, after the child turns 28 months old, the point estimate is virtually zero. However, the standard error is still very high, indicating an imprecise estimate. After the child turns three and five years old the point estimates become relatively large and positive, which is not in line with our initial hypothesis. This would imply that mothers who face negative employment incentives are more likely to become employed. But, the estimates remain statistically insignificant, based on moderate standard errors. Ten years after childbirth, the estimates are again close to zero and statistically insignificant. As expected, at all different child ages estimates based on the Probit and the OLS model are very similar. While the exclusion of control variables influences the size of the point estimate somewhat, the general results are stable. Considering these empirical findings jointly, mothers do not respond to the child care pension benefit extension in 1992 neither in the short- nor in the medium-run.

Why did mothers not react to the negative employment incentives, implied by the extension of the child care pension benefit? There are two potential channels that could explain such a behavior: A high discount factor and a short planning horizon. First, a mother with a high discount factor faces a much smaller gain from the child care pension benefit extension in 1992 compared to a mother with a low discount factor. For her, the "treatment" was simply to small in magnitude. Secondly, a mother with a short planning horizon would just not consider the dynamic impact of today's employment decision on future old-age income since her planning horizon does not cover the period when the pension benefit becomes effective. 


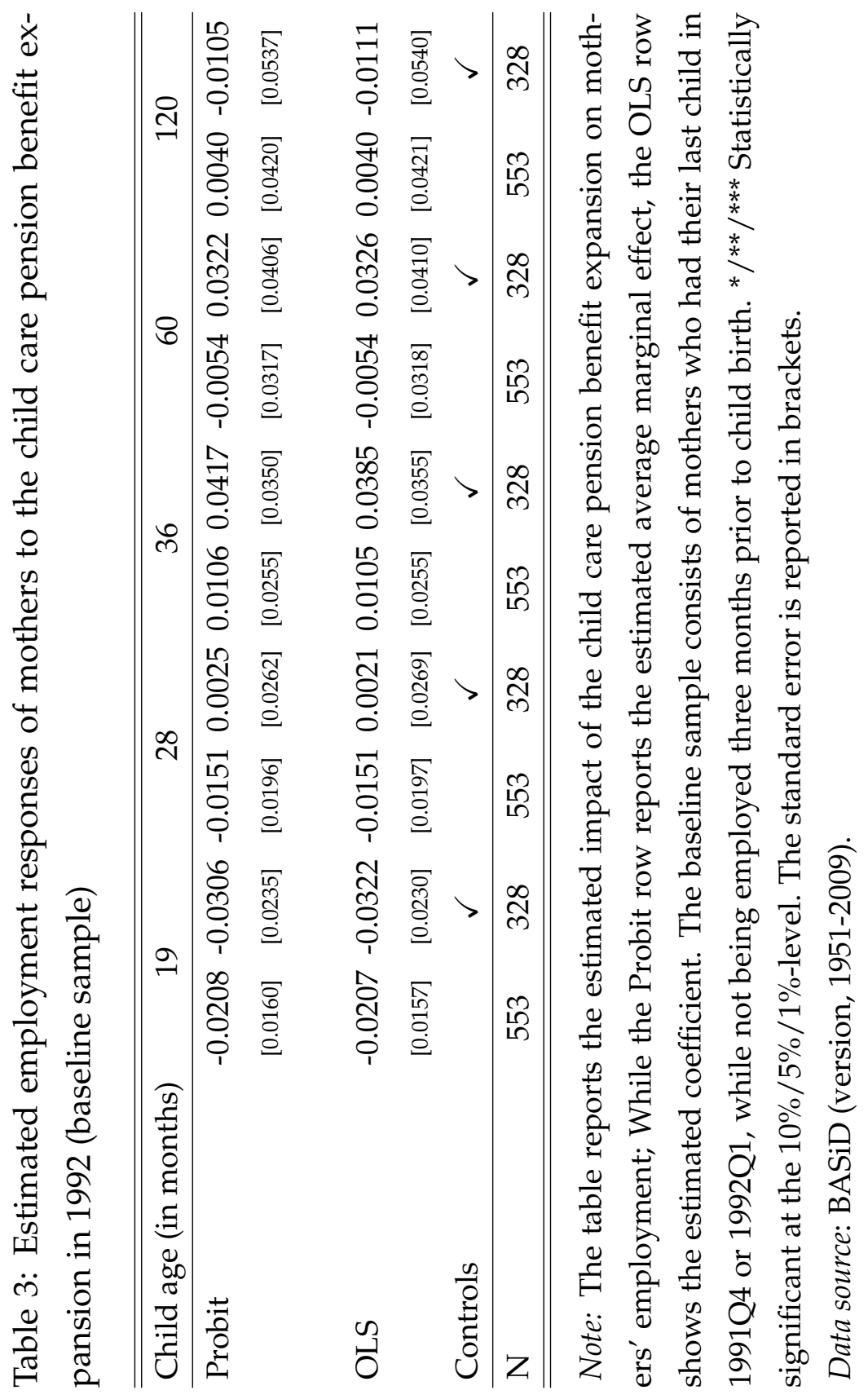




\subsection{Robustness checks}

Next, Table 4 shows the findings from several robustness checks. For brevity reasons, only estimates of the treatment effect are reported for specifications that include control variables. Detailed estimation results for all separate robustness checks are documented in the Appendix. Summarizing the results, none of the specification tests provides empirical evidence against the previous findings that the child care pension benefit does not affect a mother's employment decision in the short- or medium-run.

\section{Bandwidth variation}

First, not finding statistically significant treatment effects could potentially be driven by the small number of observations. In the baseline model, the treatment and control group consist of mothers who had a child \pm three months around the cut-offdate January 1, 1992. While it is well known that a larger sample increases efficiency, comparing mothers who gave birth to their last child further away from the cut-off date of the reform $(1 / 1 / 1992)$ is less desirable. Those mothers are more likely to differ in more dimensions than in the child care pension benefit scheme. Nevertheless, for the purpose of this robustness check a range of two quarters around the cut-offdate seems acceptable. Hence, mothers who gave birth to a child in the second half of 1991 (control group) are compared to all mothers who delivered a child in the first six months in 1992 (treatment group). A comparison of control variables across the new treatment and control group are provided by Table 5 in Appendix C. The control variables are similarly distributed across both groups, indicating a random selection of mothers into the two groups. Panel B in Table 4 reports the reform effect estimates based on the larger sample. The sample size becomes twice as large as in the baseline specification, as depicted in panel A. Depending on child age, the point estimates differ from those that are based on the baseline sample. In line with the baseline sample and regardless of child age, they are never statistically significantly different from zero.

\section{Strategic timing of child birth}

Next, I control for the potential strategic timing of a child's date of birth. Pregnant 
Table 4: Estimated employment response of mothers to the child care pension benefit extension in 1992 (alternative samples)

\begin{tabular}{lccccc}
\hline \hline Child age (in months) & 19 & 28 & 36 & 60 & 120 \\
\hline A) Baseline sample & & & & & \\
Treatment & -0.0306 & 0.0025 & 0.0417 & 0.0322 & -0.0105 \\
& {$[0.0235]$} & {$[0.0262]$} & {$[0.0350]$} & {$[0.0406]$} & {$[0.0537]$} \\
$\mathrm{N}$ & 328 & 328 & 328 & 328 & 328 \\
B) Larger bandwidth ( \pm 6 months) & & & & & \\
Treatment & -0.0194 & -0.0067 & 0.0081 & -0.0119 & 0.0121 \\
& {$[0.0170]$} & {$[0.0209]$} & {$[0.0242]$} & {$[0.0288]$} & {$[0.0371]$} \\
N & 690 & 690 & 690 & 690 & 690 \\
C) Exclusion of births around cut-off & & & & & \\
Treatment & -0.0097 & -0.0092 & 0.0102 & -0.0120 & 0.0211 \\
& {$[0.0287]$} & {$[0.0328]$} & {$[0.0429]$} & {$[0.0500]$} & {$[0.0643]$} \\
N & 229 & 229 & 229 & 229 & 229 \\
D) Control for seasonal differences & & & & & \\
Treatment & -0.0097 & 0.0152 & 0.0689 & $0.1410^{* *}$ & -0.0420 \\
& {$[0.0327]$} & {$[0.0385]$} & {$[0.0460]$} & {$[0.0549]$} & {$[0.0760]$} \\
N & 656 & 656 & 656 & 656 & 656 \\
E) Parental leave reform sensitivity sample & & & & \\
Treatment & -0.0088 & 0.0070 & 0.0125 & 0.0197 & -0.0179 \\
N & {$[0.0220]$} & {$[0.0261]$} & {$[0.0351]$} & {$[0.0406]$} & {$[0.0593]$} \\
\hline Controls & 266 & 266 & 266 & 266 & 266 \\
\hline \hline
\end{tabular}

Note: The treatment estimate refers to the average marginal effect, based on the probit model, depicted by equation 2. Only panel D) is based on difference-in-difference-regressiondiscontinuity probit model, depicted by equation 4 . All specifications include control variables (German, number of children, education, age, age squared, region, prior employment) and a constant term. ${ }^{*}{ }^{* *} / * * *$ Statistically significant at the $10 \% / 5 \% / 1 \%$-level. The standard error is reported in brackets.

The different samples are all based on mothers who had their last child around the turn of the year 1991/92 and who were not employed three months before child birth (except panel E). The baseline sample A) consists of mothers who had a child in 1991Q4 or 1992Q1; B) is based on mothers with child birth in $1991 \mathrm{H} 2$ or $1992 \mathrm{H} 1 ; \mathrm{C}$ ) is identical to A) while excluding births in December and January; D) is based on mothers who a child in 1991Q4 or 1992Q1 compared to mothers with a child in 1990Q4 or 1991Q1; E) is based on mothers who had a child in 1991Q4 or 1992Q1, but not in 1991Q1-1991Q3 nor in 1990.

Data source: BASiD (version, 1951-2009). 
women who expected the delivery around the turn of the year 1991/92 could have tried to postpone child birth to the first week of January 1992. As mentioned before, Dustmann and Schönberg (2008, Appendix A) investigate the birth patterns around the turn of the year 1991/92 without detecting irregularities. Nevertheless, parents who expected a child birth around the turn of the year 1991/92 might have wished to postpone delivery from December 1991 to January 1992. Such a behavior would invalidate the identification strategy if parents who strategically choose the child's date of birth differed systematically in terms of the employment behavior from the remaining parents. To account for this potential bias, I follow the literature (Kluve and Tamm, 2009) and re-estimate the baseline model under the exclusion of mothers who had a child either in December 1991 or in January 1992. The treatment estimates are reported in Panel C of Table 4. The point estimates differ to those based on the baseline sample. However, regardless of child age in none of the five different estimations the estimated treatment effect is statistically significantly different from zero, as in the baseline model. Consequently, the potential strategic timing of births does not impose a risk to the identification strategy.

\section{Seasonal systematic differences}

There are concerns about potential systematic differences among mothers, depending on the birth season of their child (Buckles and Hungerman, 2008). To address this issue, mothers from the baseline sample are compared to mothers who had a child in the same period around the turn of the year before, 1990/91, when no child care pension benefit reform was implemented. Following the literature, I estimate the model that has already been applied by Lalive et al. (2014) or Schönberg and Ludsteck (2014). This difference-in-difference-regression-discontinuity model can be formulated in the following way:

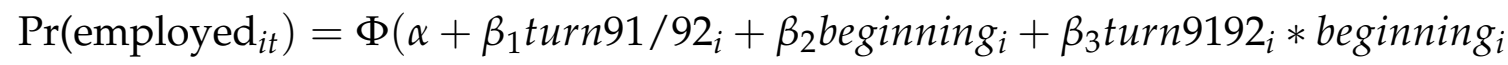

$$
\begin{aligned}
& \left.+\gamma^{\prime} X_{i t}\right)(3)
\end{aligned}
$$

where $i$ represents the mother and $t$ child age in months. $\Phi$ is the cumulative distribution function of the standard normal distribution. As in the baseline model, 
employed indicates the maternal employment status, one being employed and zero not employed. turn91/92 indicates whether a child was born around the turn of the year 1991/92 (one) or in the corresponding period the year before 1990/91 (zero). beginning equals to one if the child birth occurred in the first quarter of a year, and zero if a child was born in the last quarter. $X$ captures the vector of control variables, as in the baseline model: Age, age $e^{2}$, education, region, number of children, prior employment and German nationality. Panel D of Table 4 depicts the results. For brevity reasons it only reports the treatment effect estimate that correspond to the average marginal effect based on the interaction term turn $9192_{i} *$ beginning $_{i}$. For all five different child ages, the point estimates have the same sign and broadly a similar magnitude as the results from the baseline sample. Further, in all (except at child age of 60 months) the estimated coefficients are not statistically significantly different from zero, as in the baseline model. The only exception is five years after child birth, when the estimated treatment effect is only weakly statistically significant. All in all, the results suggest that systematic differences among mothers according to the season of birth do not seem to impose a risk for the identification strategy.

\section{Eligibility to parental leave}

In order to disentangle the impact of the child care pension benefit extension in 1992 from the impact of the simultaneously implemented parental leave expansion, I only compare mothers who were not employed in the three months prior to child birth in the baseline sample. These mothers simply do not have an employer they could return to. However, if a mother had a second child, while being on parental leave, the eligibility for parental leave was extended. Prior to 1992, parental leave was generally granted for the first 18 months after child birth. Hence, having a child in these 18 months would generally extend parental leave entitlements by another 18 months upon the subsequent child birth. In order to control for this potential source of bias, I re-estimate the model, considering only mothers who had no child in 1990 (nor in 1991 if they belong to the treatment group). These mothers could not benefit from a potential extension of the eligibility for parental leave due giving birth to another child. The treatment estimates are reported in Panel E of Table 4. At all five different child ages, the point estimates share the same sign and a similar magnitude 
with the baseline sample. In addition, all estimates remain statistically insignificant. However, the lower sample size increases the standard errors somewhat. Nevertheless, these results indicate that the theoretical parental leave eligibility of mothers in the baseline sample is unlikely and therefore it does not impose a treat to the identification strategy.

\section{Discussion and conclusion}

In this paper I estimate the effect of pension wealth on maternal employment in the period following child birth. For this purpose I exploit a variation in pension wealth given by the extension of the German child care pension benefit in 1992 as a natural experiment. Child care pension benefits generally increase a mother's pension entitlements in periods when child care precludes work.

The pension reform 1992 extended the provision period of the child care pension benefit from one to three years for all newborns, starting in January 1992. This reform design allows comparing the employment status of mothers who had a child in the last quarter 1991 to mothers who had a child in the first quarter 1992. While all mothers had a child around the turn of the year 1991/1992, only the latter group could take advantage of the longer provision period of the child care pension benefit. However, the child care pension benefit reform coincided with the extension of parental leave for child births from January 1992. To isolate the effect from the two reforms, I only compare mothers who were not employed three months prior to child birth. They are generally only affected by the change in child care pension benefits. While this strategy restricts the sample slightly, the findings are still representative for the large group of mothers with a weaker attachment to the labor market.

The results indicate that the child care pension benefit does not affect mothers employment, neither in the short- nor in the medium-run. However, some caution has to be applied due to the limited sample size. The analysis of employment reactions to family benefits granted upon child birth is particularly important as the length of employment interruptions pave the way for the individual long-term earnings potential. Not finding negative employment reactions to higher pension wealth can 
therefore be deemed positive since it does not harm a mother's earnings perspective.

In addition, the findings can be interpreted as empirical evidence against rational behavior among mothers. A rational mother would have reduced her employment in response to the economic incentives of the child care pension benefit. Potential explanations could be a large discount factor of future pension benefits or a short planning horizon.

Finally from a policy perspective, the empirical results are important. Child care pension benefits are designed to compensate mothers for pension entitlements that could not be accrued because periods of child care precluded employment. The empirical findings show that the child care pension benefit compensates mothers by increasing their old-age income without causing negative employment reactions in the short- and medium-run. 


\section{References}

Albrecht, J. W., Edin, P.-A., Sundström, M., and Vroman, S. B., 1999. Career Interruptions and Subsequent Earnings: A Reexamination Using Swedish Data. The Journal of Human Resources, 34(2):294-311.

Anderson, P. M. and Levine, P. B., 1999. Child Care and Mothers' Employment Decisions. NBER Working Papers 7058, National Bureau of Economic Research.

Angrist, J. D. and Lavy, V., 1999. Using Maimonides' Rule to Estimate the Effect of Class Size on Scholastic Achievement. The Quarterly Journal of Economics, 114(2):533-575.

Bauernschuster, S. J. and Schlotter, M., 2013. Public Child Care and Mothers' Labor Supply - Evidence from Two Quasi-Experiments. CESifo Working Paper Series 4191, CESifo Group Munich.

Baum, I. and Charles, L., 2003. The effect of state maternity leave legislation and the 1993 Family and Medical Leave Act on employment and wages. Labour Economics, 10(5):573-596.

vom Berge, P., König, M., and Seth, S., 2013. Sample of Integrated Labour Market Biographies (SIAB) 1975-2010. Technical report, Research Data Center (FDZ) at the Institute for Employment Research (IAB).

Bergemann, A. and Riphahn, R. T., 2010. Female labour supply and parental leave benefits. The causal effect of paying higher transfers for a shorter period of time. Applied Economics Letters, 18(1):17-20.

Berkel, B. and Börsch-Supan, A., 2004. Pension reform in Germany: The impact on retirement decisions. FinanzArchiv: Public Finance Analysis, 60(3):393-421.

Bettendorf, L., Jongen, E. L., and Muller, P., 2012. Childcare Subsidies and Labor Supply: Evidence from a large Dutch Reform. Tinbergen Institute Discussion Paper 12-093/I, Tinbergen Institute, Amsterdam and Rotterdam. 
Blau, D. and Currie, J., 2006. Chapter 20 Pre-School, Day Care, and After-School Care: Who's Minding the Kids? In Hanushek, E. and Welch, F., editors, Handbook of the Economics of Education, volume 2 of Handbook of the Economics of Education, pages 1163 - 1278. Elsevier.

Blau, D. and Tekin, E., 2007. The Determinants and Consequences of Child Care Subsidies for Single Mothers in the USA. Journal of Population Economics, 20(4):719741.

Boersch-Supan, A. and Wilke, C. B., 2004. The German Public Pension System: How it Was, How it Will Be. Working Paper 10525, National Bureau of Economic Research.

Buckles, K. and Hungerman, D. M., 2008. Season of Birth and Later Outcomes: Old Questions, New Answers. Working Paper 14573, National Bureau of Economic Research.

Cascio, E. U., 2009. Maternal Labor Supply and the Introduction of Kindergartens into American Public Schools. Journal of Human Resources, 44(1):31.

Dustmann, C. and Schönberg, U., 2011. Expansions in Maternity Leave Coverage and Children's Long-Term Outcomes. American Economic Journal: Applied Economics, 4(3):190-224.

Dustmann, C. and Schönberg, U., 2008. The effect of expansions in maternity leave coverage on children's long-term outcomes. Technical report, IZA Discussion Paper Series, 3605.

Ekberg, J., Eriksson, R., and Friebel, G., 2013. Parental leave. A policy evaluation of the Swedish Daddy-Month reform. Journal of Public Economics, 97(0):131 - 143.

Faik, J. and Köhler-Rama, T., 2009. Für eine Rentenanpassung mit Sicherungsziel. Wirtschaftsdienst, 89(9):601-609.

Fitzenberger, B., Osikominu, A., and Völter, R., 2005. Imputation Rules to Improve the Education Variable in the IAB Employment Subsample. Technical report, Bundesagentur für Arbeit. 
Fitzpatrick, M. D., 2010. Preschoolers Enrolled and Mothers at Work? The Effects of Universal Prekindergarten. Journal of Labor Economics, 28(1):51-85.

Gale, W. G., 1998. The Effects of Pensions on Household Wealth: A Reevaluation of Theory and Evidence. Journal of Political Economy, 106(4):706-723.

Gans, J. S. and Leigh, A., 2009. Born on the first of July: An (un)natural experiment in birth timing. Journal of Public Economics, 93:246 - 263.

Geyer, J., Haan, P., and Wrohlich, K., 2014. The Effects of Family Policy on Mothers' Labor Supply: Combining Evidence from a Structural Model and a Natural Experiment. Discussion Papers of DIW Berlin 1366, DIW Berlin, German Institute for Economic Research.

Geyer, J. and Steiner, V., 2014. Future public pensions and changing employment patterns across birth cohorts. Journal of Pension Economics and Finance, 13:172-209.

Givord, P. and Marbot, C., 2013. Does the cost of child care affect female labor market participation? An evaluation of a French reform of childcare subsidies. Documents de Travail de la DESE - Working Papers of the DESE g2013-04, Institut National de la Statistique et des Etudes Economiques, DESE.

Gruber, J. and Wise, D. A., 2002. Social Security Programs and Retirement Around the World: Micro Estimation. Working Paper 9407, National Bureau of Economic Research.

Guner, N., Kaygusuz, R., and Ventura, G., 2013. Childcare Subsidies and Household Labor Supply. Working Papers 738, Barcelona Graduate School of Economics.

Gustman, A. L. and Steinmeier, T. L., 2005. The social security early entitlement age in a structural model of retirement and wealth. Journal of Public Economics, 89:441 $-463$.

Haan, P. and Wrohlich, K., 2011. Can child care policy encourage employment and fertility? Evidence from a structural model. Labour Economics, 18(4):498-512. 
Hanel, B., 2010. Financial incentives to postpone retirement and further effects on employment - Evidence from a natural experiment. Labour Economics, 17(3):474486.

Havnes, T. and Mogstad, M., 2011. Money for nothing? Universal child care and maternal employment. Journal of Public Economics, 95(11):1455-1465.

Hochfellner, D., Müller, D., and Wurdack, A., 2012. Biographical Data of Social Insurance Agencies in Germany - Improving the Content of Administrative Data. Schmollers Jahrbuch: Journal of Applied Social Science Studies/Zeitschrift für Wirtschafts-und Sozialwissenschaften, 132(3):443-451.

Klerman, J. A. and Leibowitz, A., 1999. Job continuity among new mothers. Demography, 36(2):145-155.

Kluve, J. and Tamm, M., 2009. Now daddy's changing diapers and mommy's making her career: Evaluating a generous parental leave regulation using a natural experiment. Ruhr Economic Papers 145, RWI, Essen.

Lalive, R., Schlosser, A., Steinhauer, A., and Zweimüller, J., 2014. Parental leave and mothers' careers: The relative importance of job protection and cash benefits. The Review of Economic Studies, 81:219-265.

Lalive, R. and Zweimüller, J., 2009. How Does Parental Leave Affect Fertility and Return to Work? Evidence from Two Natural Experiments. The Quarterly Journal of Economics, 124(3):1363-1402.

Lee, D. S. and Lemieux, T., 2010. Regression Discontinuity Designs in Economics. Journal of Economic Literature, 48(2):281-355.

Lefebvre, P., Merrigan, P., and Verstraete, M., 2009. Dynamic labour supply effects of childcare subsidies: Evidence from a Canadian natural experiment on low-fee universal child care. Labour Economics, 16(5):490 - 502.

Lundin, D., Mörk, E., and Öckert, B., 2008. How far can reduced childcare prices push female labour supply? Labour Economics, 15(4):647 - 659. 
Mincer, J. and Ofek, H., 1982. Interrupted Work Careers: Depreciation and Restoration of Human Capital. The Journal of Human Resources, 17(1):3-24.

Neugart, M. and Ohlsson, H., 2013. Economic incentives and the timing of births: Evidence from the German parental leave reform of 2007. Journal of Population Economics, 26:87-108.

Nollenberger, N. and Rodriguez-Planas, N., 2011. Child care, maternal employment and persistence: A natural experiment from Spain. IZA Discussion Paper 5888, IZA, Bonn.

Oreopoulos, P., 2006. Estimating Average and Local Average Treatment Effects of Education When Compulsory Schooling Laws Really Matter. The American Economic Review, 96(1):152-175.

Rainer, H., Bauernschuster, S., Danzer, N., Hener, T., Holzner, C., and Reinkowski, J., 2012. Kindergeld. Technical report, ifo Forschungsberichte, 60.

Ruhm, C. J., 1998. The Economic Consequences of Parental Leave Mandates: Lessons from Europe. The Quarterly Journal of Economics, 113(1):285-317.

Schönberg, U. and Ludsteck, J., 2014. Expansions in Maternity Leave Coverage and Mothers Labor Market Outcomes after Childbirth. Journal of Labor Economics, 32(3):469-505.

Shapiro, D. and Mott, F. L., 1994. Long-Term Employment and Earnings of Women in Relation to Employment Behavior Surrounding the First Birth. The Journal of Human Resources, 29(2):248-275.

Tamm, M., 2012. The Impact of a Large Parental Leave Benefit Reform on the Timing of Birth around the Day of Implementation. Oxford Bulletin of Economics and Statistics.

Waldfogel, J., 1999. The impact of the Family and Medical Leave Act. Journal of Policy Analysis and Management, 18(2):281-302. 


\section{Appendix}

\section{A Calculation of the net present value of the gain from the child care pension benefit extension in 1992}

This section calculates the maximum gain from the child care pension benefit extension in 1992 for a reference mother in net present values (NPV) in 1992. It compares the monetary equivalent of the child care pension benefit at retirement of a mother who has a child shortly after the date of reform implementation, i.e. after January 1, 1992 to having the child shortly before that date, e.g. in December 1991. The calculation is based on the following scenario:

- The legal framework that was in place in 1992.

- A mother is entitled to old-age pension.

- She is 30 years old at the date of child birth.

- She retires at the age of 65 .

- Her life expectancy is set to 83 years. ${ }^{13}$

- The discount rate $z$ is set to 0.03 .

- The maximum gain from the reform in pension points is 1.5 per month. In 2012, a pension point translates into EUR 28 per month. Hence the annual gain, in 2012 values, is EUR $28 * 1.5 * 12=$ EUR 504 .

$\mathrm{NPV}_{\text {reformgain }}=\frac{504}{(1+z)^{35}}+\frac{504}{(1+z)^{36}}+\ldots+\frac{504}{(1+z)^{53}}=\sum_{t=35}^{53} \frac{504}{(1+z)^{t}}=2,642.5[$ EUR $]$

The maximum gain due to the child care pension benefit extension is EUR 2,643.

\footnotetext{
${ }^{13}$ According to calculations of the Federal Statistical Office, life expectancy of a women born in 1969 amounts to 83 - 84 years (https://www.destatis.de/DE/ZahlenFakten/GesellschaftStaat/ Bevoelkerung/Sterbefaelle/Tabellen/ModellrechnungLebenserwartung.html).
} 


\section{B Did the child care pension benefit extension 1992 affect timing of births?}

This section investigates birth patterns around ( \pm 6 months) the extension of the child care pension benefit in 1992 and subsequent years. The reform provides incentives for parents to have a child after December 1991. If parents strongly respond to the reform by strategically adjusting the timing of child births, then we would expect to find such a behavior in the birth statistics. The following analysis compares the birth pattern between July 1991 and June 1994 based on the vital statistics 1991, 1992, 1993 and 1994. The data covers all registered births in West Germany. Figure 4 shows the absolute number of births per month. Parents who wanted to strategically select into the treatment group would prefer to have their child after December 1991. Hence, in the first series 1991H2/92H1 we would expect lower birth rates in the months before and higher rates after the turn of the year compared to the subsequent periods. Focusing on the second half-year 1991, the distribution of births per months is similar across the three years. This is also true for the first half-year 1992. Hence, the plot does not provide evidence for a systematic difference in the birth pattern across the period of analysis. However, the comparison based solely on the absolute number of births could lead to false conclusions if the total number of births differed substantially across the years. Hence, Figure 5 relates the number of monthly births to the period average. Accordingly, the y-axis reports the monthly share of total births in the period. In comparison, to Figure 4 the general pattern persists. The plot confirms the previous result. There is no evidence indicating that birth in 1991H2/92H1 differing systematically from the subsequent years. These findings are in line with Dustmann and Schönberg (2008). They, compare births shortly around the turn of the year 1991/92 based on vital statistics for the West German states Bavaria, Hesse, and Schleswig-Holstein. 
Figure 4: Number of births by month, July 1991 - June1994

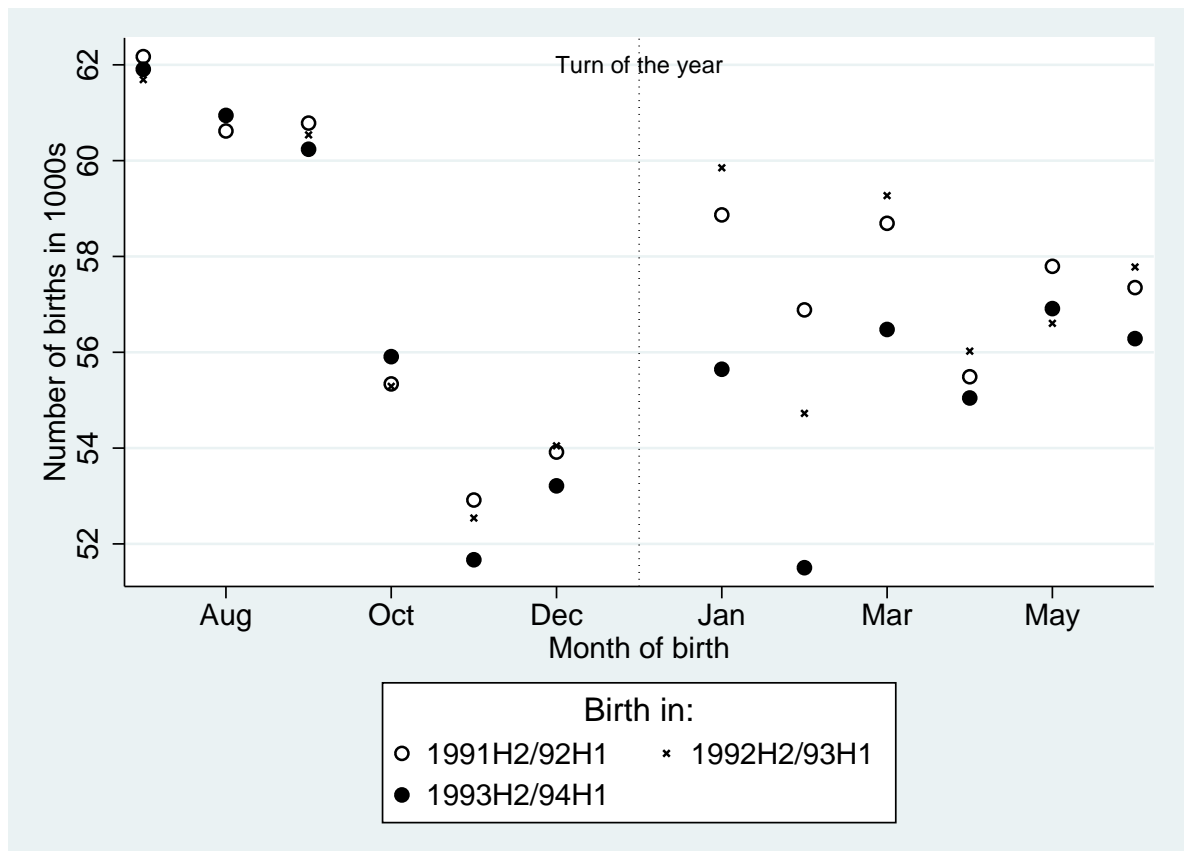

Notes: The data covers all births between July 1991 and June 1994 in West Germany. Data source: Vital statistics 1991, 1992, 1993 and 1994.

Figure 5: Relative number of births by month, July 1991 - June 1994

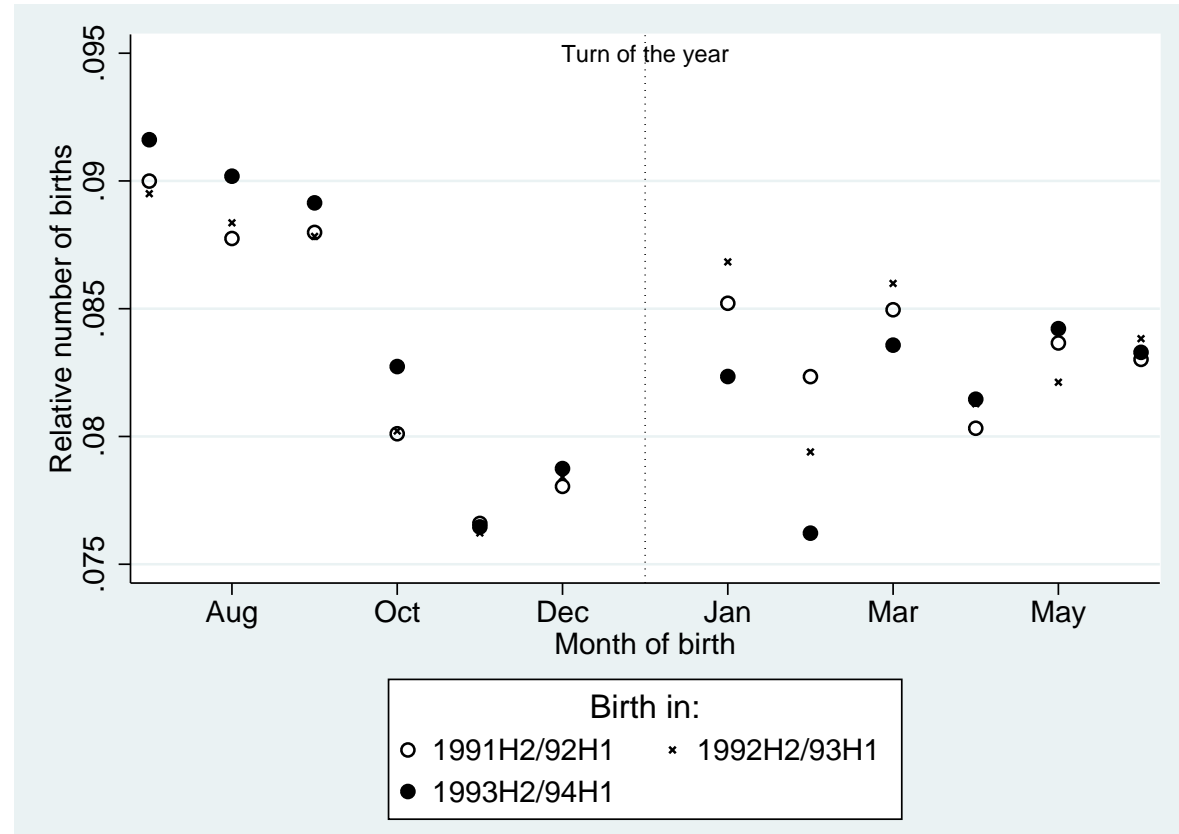

Notes: The data covers all births between July 1991 and June 1994 in West Germany. Monthly number of births are divided by the group average.

Data source: Vital statistics 1991, 1992, 1993 and 1994. 


\section{Further descriptives}

Table 5: Comparison of observable characteristics across Treatment- and Control group based on a larger bandwidth (births around January 1, $1992 \pm 6$ months)

\begin{tabular}{l|cccc|cccc|c}
\multicolumn{3}{c|}{} & \multicolumn{3}{c|}{ Treatment } & \multicolumn{3}{c|}{ Control } & Group \\
& group (N=352) & \multicolumn{3}{c}{ Group (N=338) } & Difference $^{1}$ \\
& Mean & SD & Min & Max & Mean & SD & Min & Max & \\
\hline Prior employment (years) & 3.56 & 4.11 & 0 & 28.05 & 3.88 & 4.09 & 0 & 23.89 & -.32 \\
Mother's age at delivery & 28.7 & 5.20 & 18 & 43 & 28.3 & 4.84 & 19 & 44 & .4 \\
German (0/1) & .72 & & 0 & 1 & .75 & & 0 & 1 & -.03 \\
Number of children & 2.09 & 1.18 & 1 & 7 & 2.01 & .99 & 1 & 8 & .08 \\
Higher education $(0 / 1)$ & .13 & & 0 & 1 & .15 & & 0 & 1 & -.02 \\
Region & & & & & & & & & \\
North $(0 / 1)$ & .16 & & 0 & 1 & .20 & & 0 & 1 & -.04 \\
Middle $(0 / 1)$ & .49 & & 0 & 1 & .45 & & 0 & 1 & .04 \\
South $(0 / 1)$ & .35 & 0 & 1 & .35 & 0 & 1 & 0 \\
\hline
\end{tabular}

Notes: Only mothers who had their last child and who were not employed three months prior to child birth are part of the sample. The treatment group consists of mothers who had a child in 1992H1 and in the control group are mothers who had their child in 1991H2. Higher education indicates a secondary, intermediate school leaving certificate with completed vocational training or a higher education level. Region captures the different regions of residence based on the states of residence: North (Schleswig-Holstein, Hamburg, Bremen, Lower Saxony), Middle (North Rhine-Westphalia) and South (Baden-Wuerttemberg and Bavaria).

1) None of the variables is statistically significantly different across the two groups ( $95 \%$-level).

Data source: BASiD (version, 1951-2009). 


\section{Supplementary regression results}

\section{Re-estimation of the model of Schönberg and Ludsteck (2014)}

In this section, I re-estimate the model of Schönberg and Ludsteck (2014, cf. Table 1 , reform 4, p. 487) that evaluates the German parental leave extension from 18 to 36 months in 1992 using BASiD. ${ }^{14}$ While the BASiD data set is relatively similar to the Social Security Records that Schönberg and Ludsteck (2014) use, there is a striking difference. The latter has a larger sample size of more than 200,000 mothers, while BASiD is substantially smaller. Despite that, the data sets are relatively similar since BASiD is constructed based on several administrative data sets, and the Social Security Records data is one of them (vom Berge et al., 2013; Hochfellner et al., 2012). If the estimation of the model based on BASiD leads to similar results, this would support the presumption that results based on BASiD are indeed comparable to empirical findings based on the Social Security Records. I follow Schönberg and Ludsteck (2014) and select mothers who had their last child in 1991Q4 or 1992Q1, respectively in 1990Q4 or 1991Q1 - independent on their pre-child birth employment status - into the sample. Table 11 in Appendix D reports the results. According the estimates based on BASiD, mothers have on average a 12 percentage points lower employment probability when a child is 19 months old, if they experience the extended parental leave duration. In comparison, Schönberg and Ludsteck (2014, Table 1, Reform 4, p. 487) obtain an estimate of about -10 percentage points. While, the standard errors are larger due to the smaller sample, the point estimates are broadly in line with Schönberg and Ludsteck (2014) at later child ages.

\footnotetext{
${ }^{14}$ Precisely, I re-estimate the following OLS model:

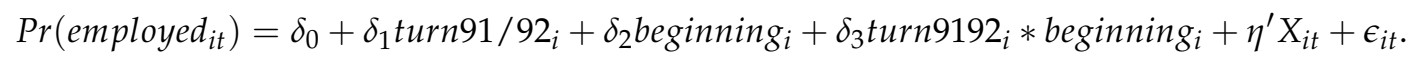

where $i$ indicates the mother and $t$ child age in months. turn91/92 indicates whether a child was born around the turn of the year 1991/92 (one) or in the corresponding period the year before 1990/91 (zero). beginning captures the impact of being born in the first quarter, in comparison to being born in the last quarter. $X$ captures the same vector of control variables as in the baseline model, as described before. The interaction term turn $91 / 92 *$ beginning captures the impact of being affected by the parental leave expansion on maternal employment. $\epsilon$ is the error term.
} 


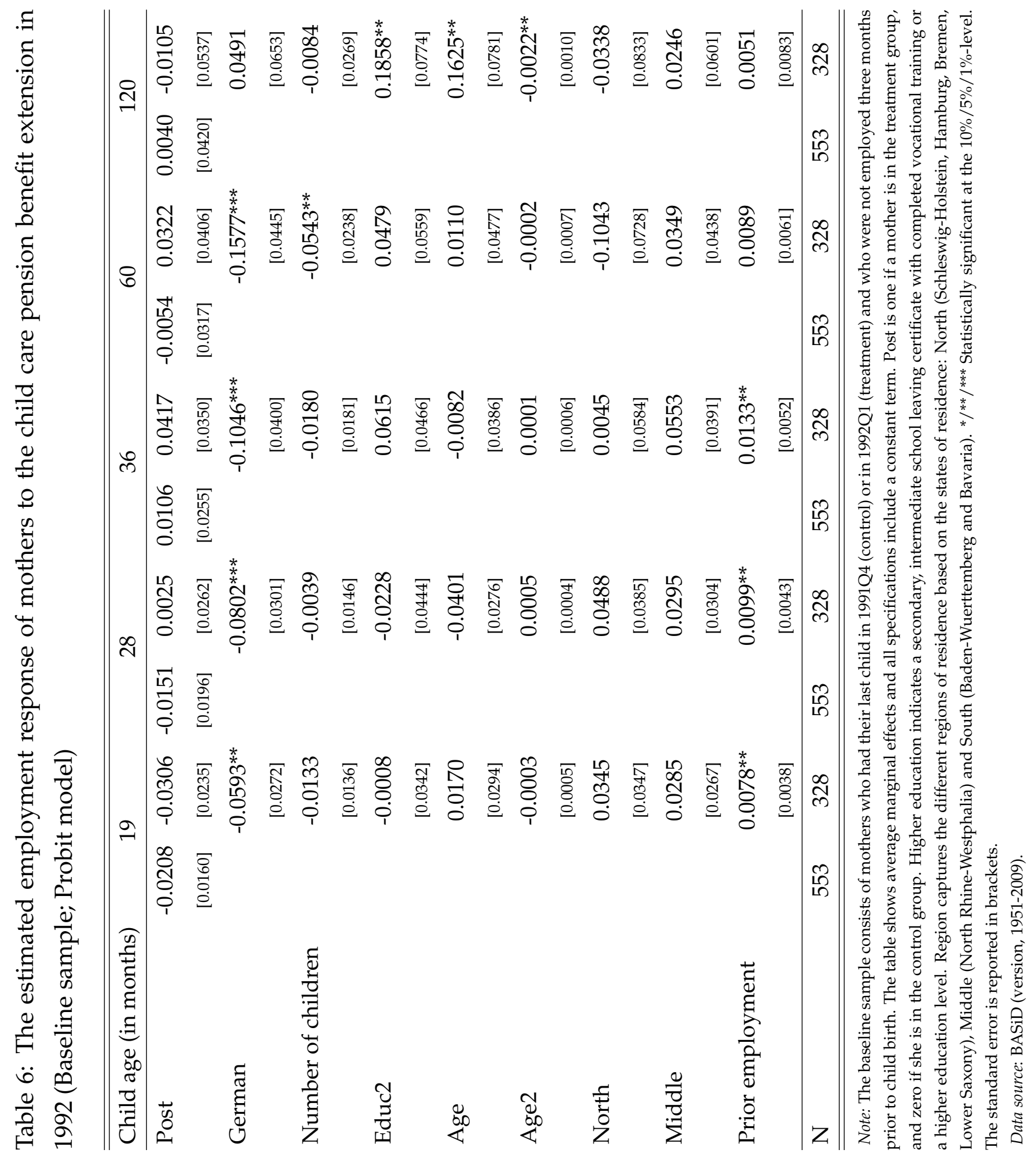




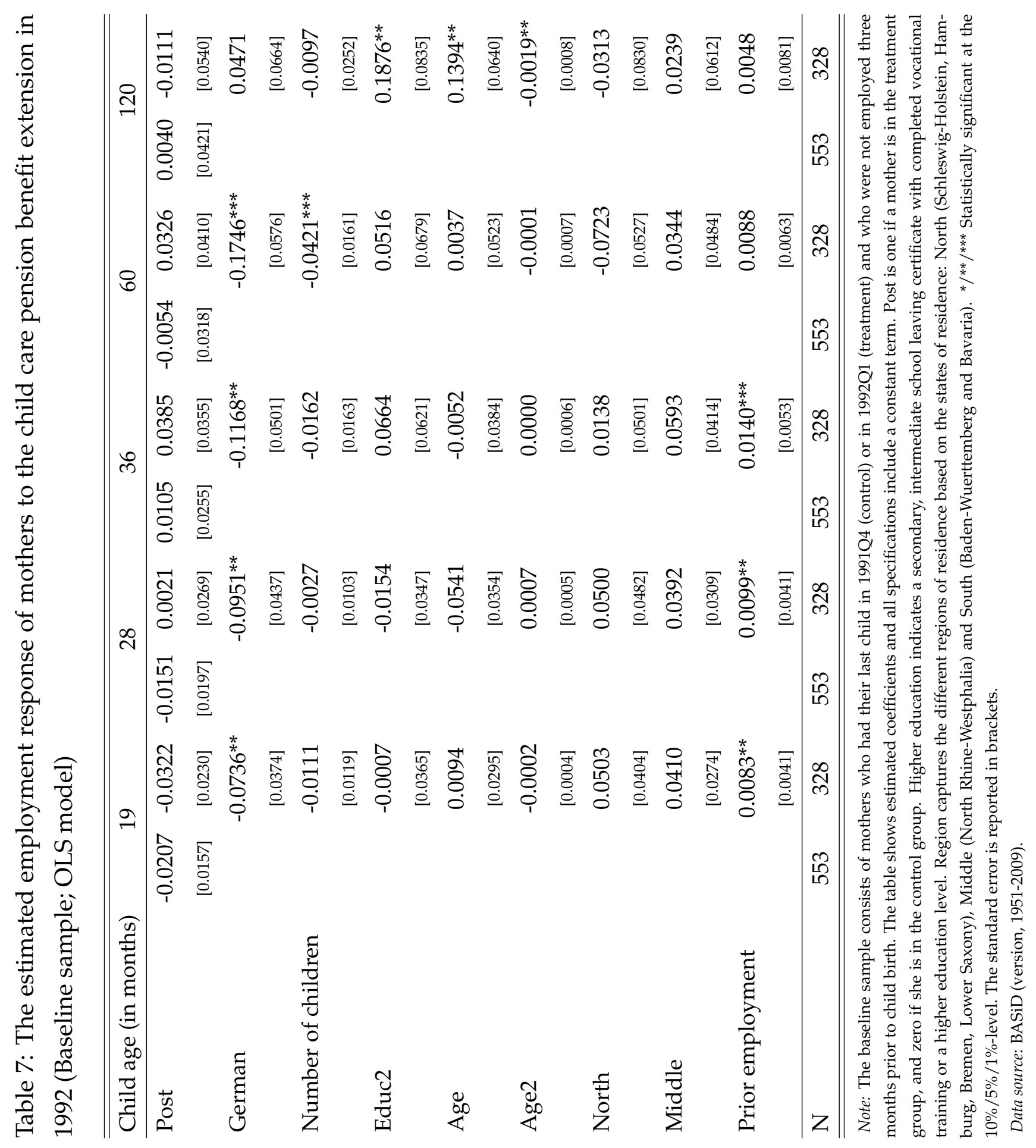




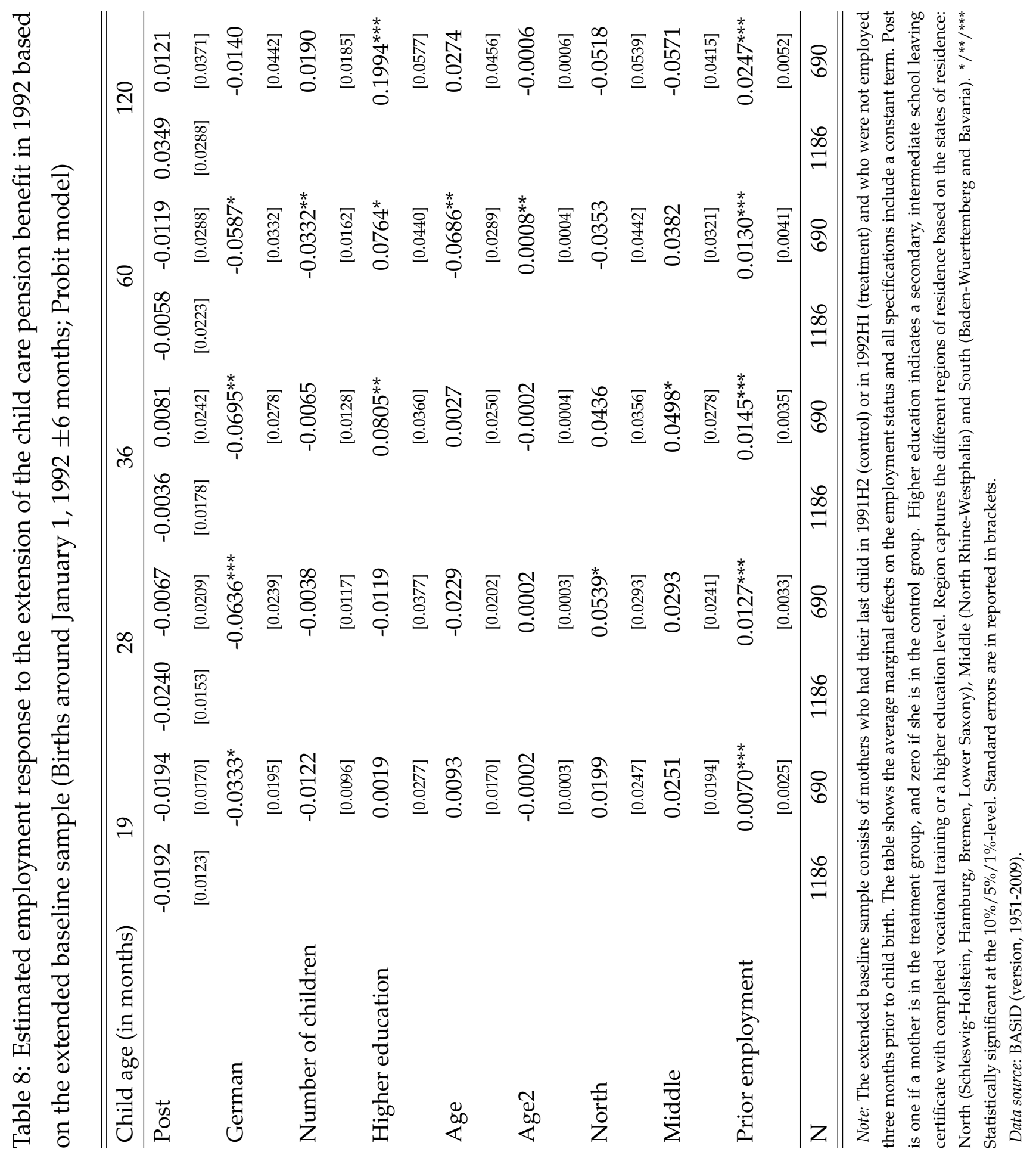




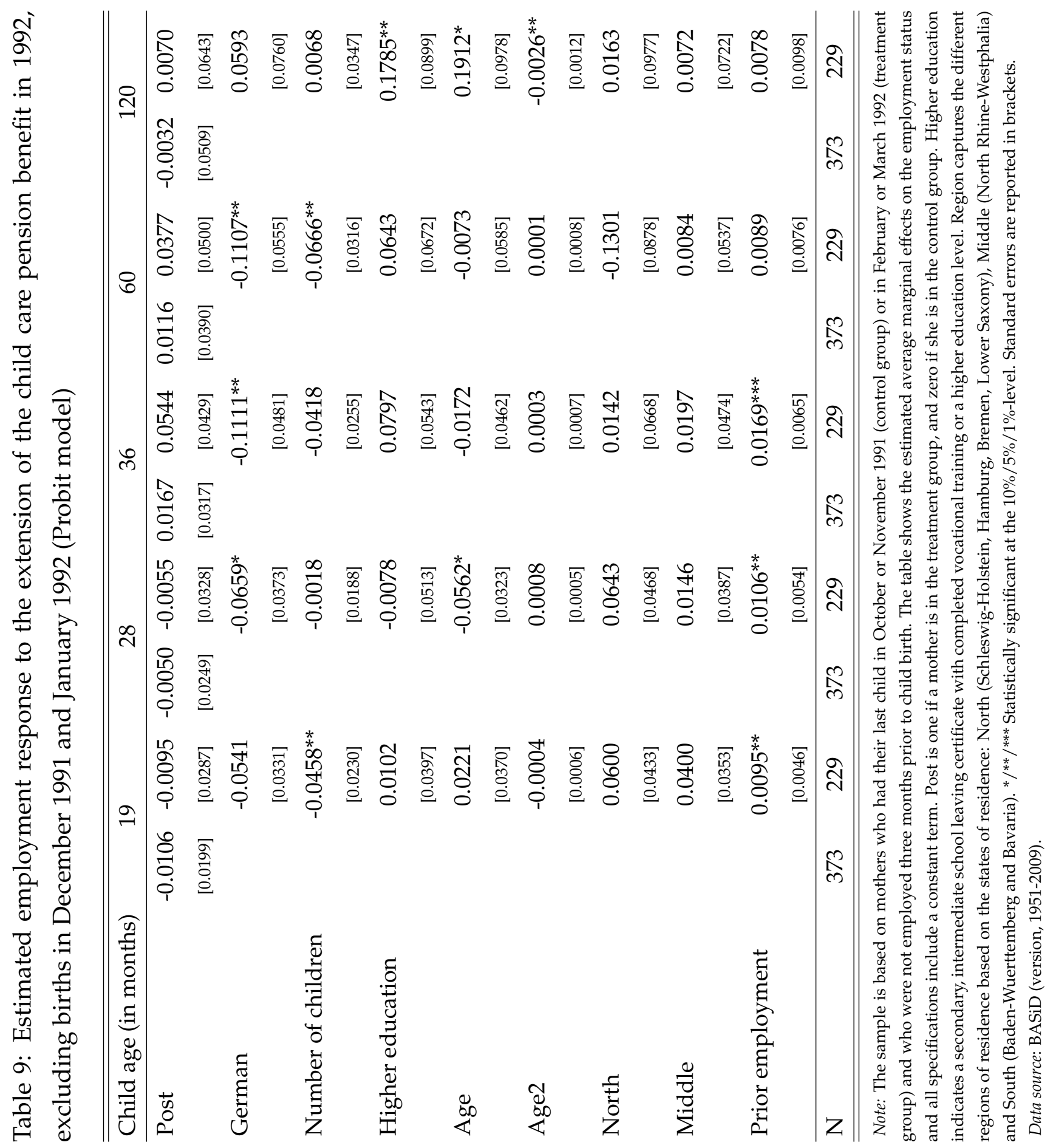




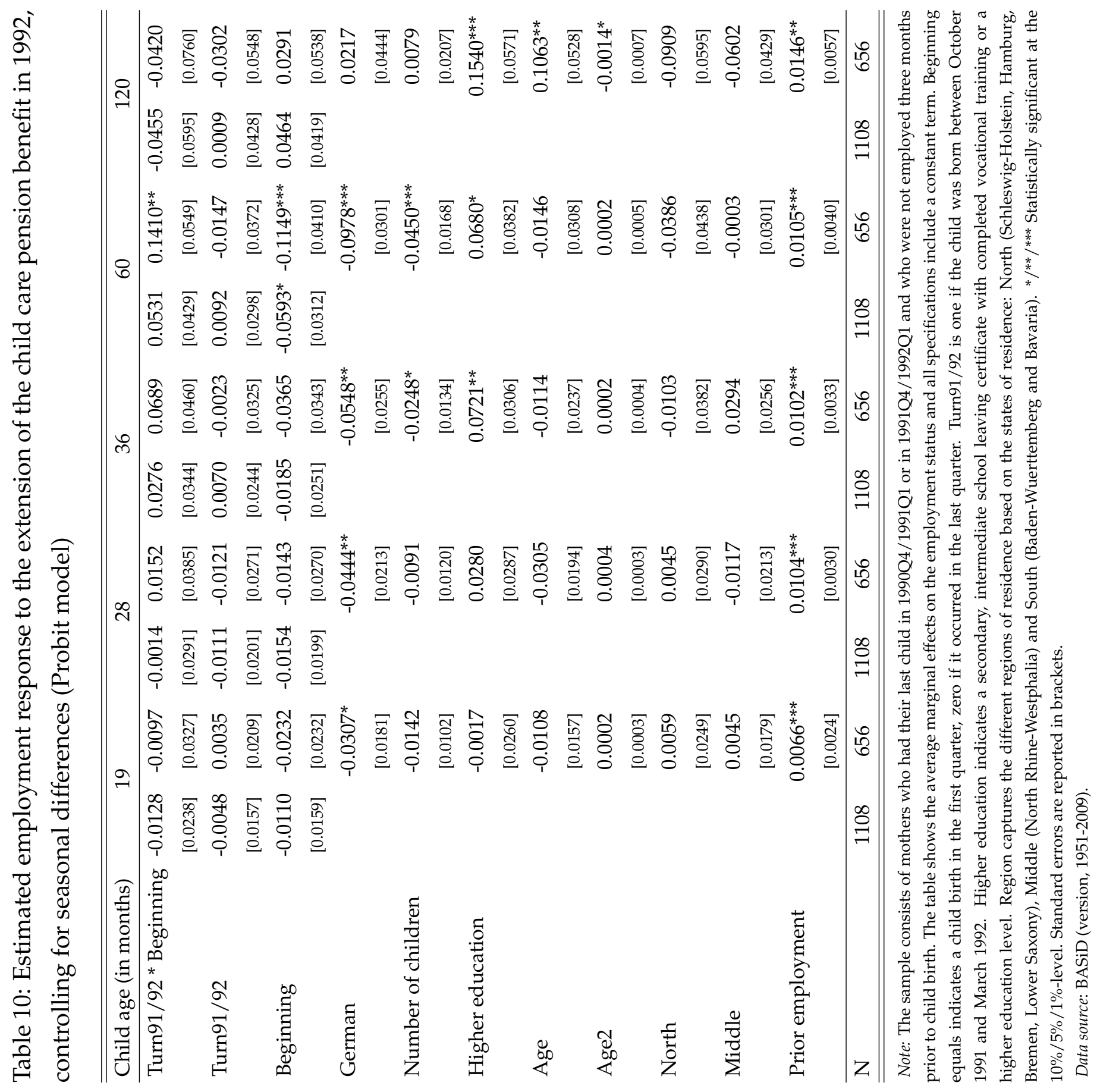




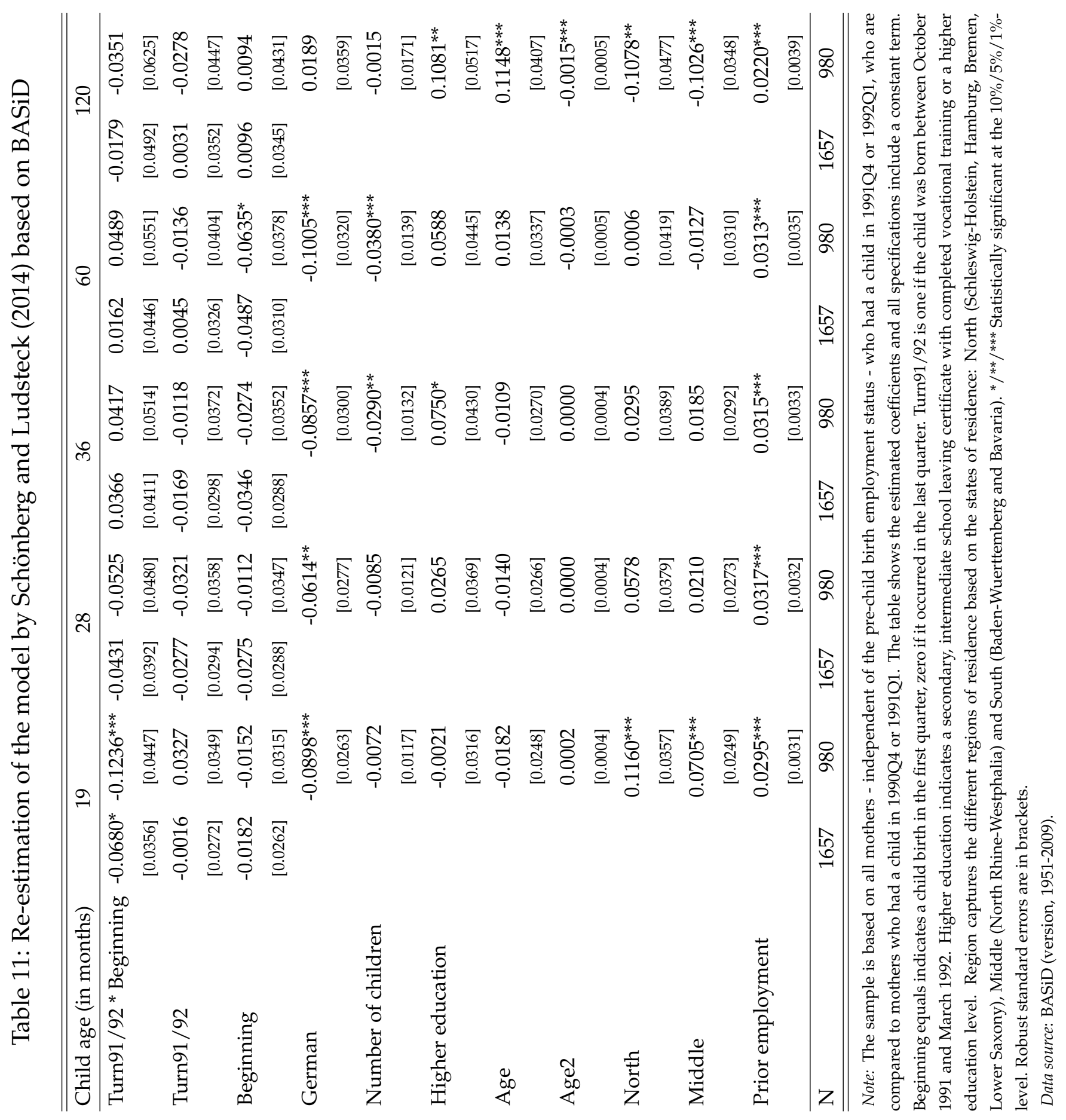




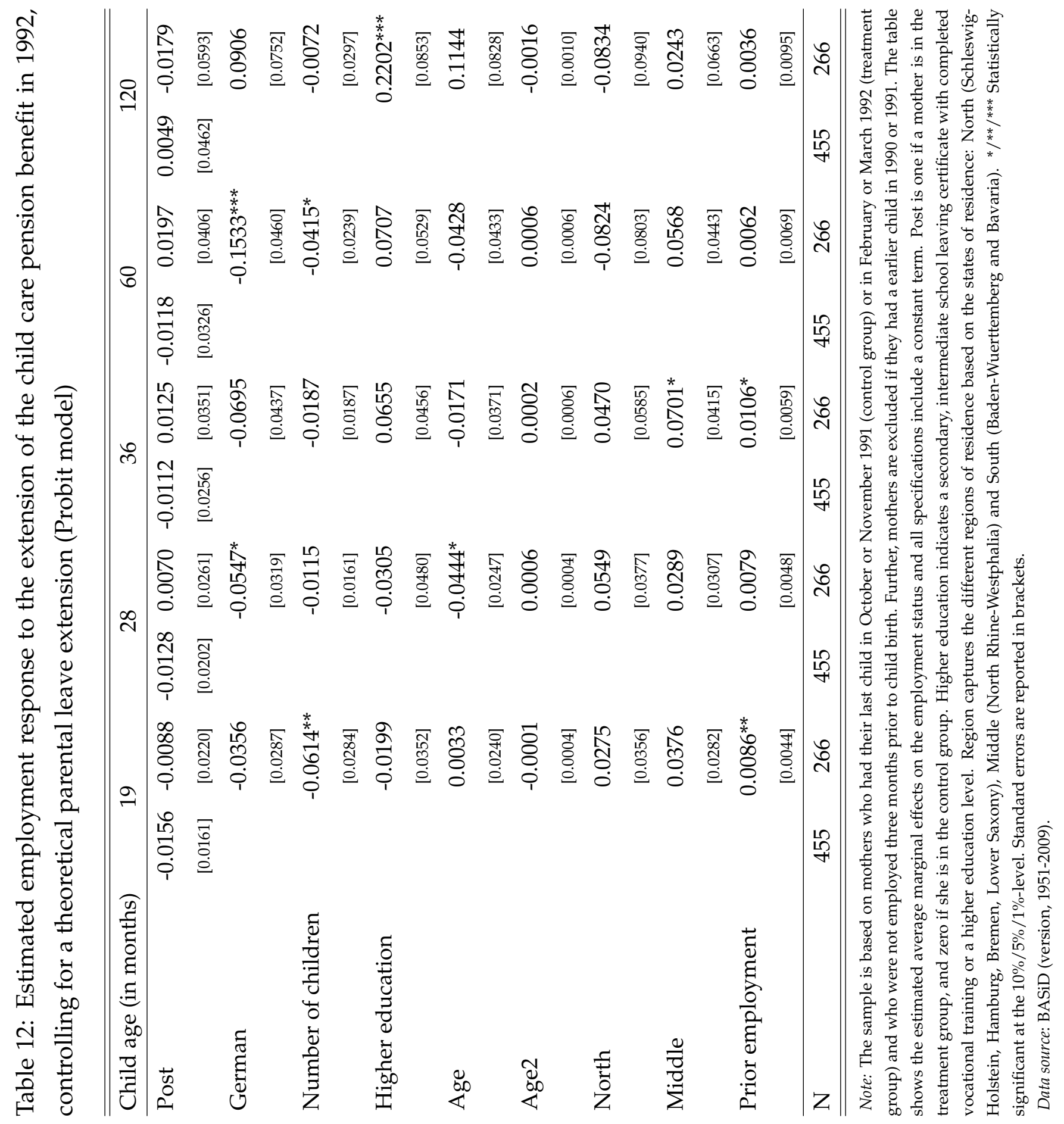

